\title{
An Additively Manufactured Titanium Alloy in the Focus of Metallography
}

\section{Eine additiv gefertigte Titanlegierung im Fokus der Metallographie}

Received: June 05, 2020

Accepted: August 26, 2020

Translation: E. Engert

\section{Abstract}

Additive manufacturing processes allow the production of geometrically complex lightweight structures with specific material properties. However, by contrast with ingot metallurgy methods, the manufacture of components using this process also brings about some challenges. In the field of microstructural characterization, where mostly very fine structures are analyzed, it is thus indispensable to optimize the classic sample preparation process and to furthermore implement additional preparation steps. This work focuses on the metallography of additively manufactured Ti-6Al-4V components produced in a selective laser melting process. It offers a guideline for the metallographic preparation along the process chain of additive manufacturing from the metal powder characterization to the macro- and microstructural analysis of the
Eingegangen: 05. Juni 2020

Angenommen: 26. August 2020

\section{Kurzfassung}

Additive Fertigungsprozesse ermöglichen die Herstellung von geometrisch komplexen Leichtbaustrukturen mit spezifischen Werkstoffeigenschaften. Die Bauteilfertigung über diesen Prozess bringt aber, im Vergleich zu den schmelzmetallurgischen Verfahren, einige Herausforderungen mit sich. So auch im Bereich der Mikrostrukturcharakterisierung des meist sehr feinen Gefüges, wobei es unumgänglich ist, die klassische Probenpräparation zu optimieren sowie darüber hinaus zusätzliche Präparationsschritte zu implementieren. Diese Arbeit beschäftigt sich mit der Metallographie von additiv gefertigten Ti-6Al-4V-Bauteilen, hergestellt durch selektives Laserschmelzen. Beginnend bei der Metallpulvercharakterisierung bis hin zur makro- und mikrostrukturellen Analyse der lasergeschmolzenen Probenkörper bietet diese Arbeit einen Leitfaden für die metallographische Präparation entlang der

\section{Authors:}

Christian Fleißner-Rieger, Thomas Pogrielz, David Obersteiner, Helmut Clemens, Svea Mayer Department Werkstoffwissenschaft, Montanuniversität Leoben, Franz-Josef Straße 18, 8700 Leoben, Österreich; e-mail: christian.fleissner-rieger@unileoben.ac.at Tanja Pfeifer Pankl Systems Austria GmbH, Additive Manufacturing Technologies, Industriestraße Ost 4, 8605 Kapfenberg, Österreich 
laser melted sample. Apart from developing preparation parameters, selected etching methods were examined with regard to their practicality.

\section{Introduction}

The production of metallic structural components by additive manufacturing, AM, has become established in the last two decades. Universities and research institutions have considerably contributed to its use in industrial applications. This method is also already established in the manufacture of lightweight construction materials such as titanium and titanium alloys. It is used in the aviation sector, in medical technology, and in the automotive and ship building industry in the production of partially complex components that are, for instance, subjected to elevated temperatures and corrosive media [1]. Titanium alloys are classified as $\alpha$, near- $\alpha, \alpha+\beta$ and $\beta$ alloys depending on their alloying elements [2]. The $\alpha+\beta$ alloy Ti-6Al$4 \mathrm{~V}(\mathrm{~m} . \%)$ is the most frequently used titanium alloy $[3,4]$. Components made of this alloy are, for instance, manufactured using a powder bed-based selective laser melting technique (Laser Powder Bed Fusion, LPBF). Against the backdrop of a process and product quality assurance process, the material is characterized - from the initial metallic powder to the additively manufactured solid material sample. The quality of the end product is closely linked with the powder quality. Parameters such as chemical composition, flow behavior, tap and bulk density, sphericity, porosity, and particle size distribution are therefore analyzed [5]. The main focus of the examination of the additively manufactured Ti-6Al-4V samples is on microstructural characteristics such as structural homogeneity, appearance of the hexagonal (hex) martensitic $\alpha^{\prime}$ phase, and phase fractions $[6,7]$. The AM process generates microstructures that differ fundamentally from those generated based on
Prozesskette der additiven Fertigung. Neben der Entwicklung von Präparationsparameter wurden ausgewählte Ätzmethoden auf ihre Durchführbarkeit untersucht.

\section{Einleitung}

Die Herstellung von metallischen Strukturbauteilen über additive Fertigungsverfahren (engl.: Additive Manufacturing, AM) ist in den letzten 20 Jahren etabliert worden. Universitäten und Forschungseinrichtungen haben wesentlich dazu beigetragen, dass $\mathrm{AM}$ in industriellen Anwendungen zum Einsatz kommt. Auch im Bereich der Leichtbauwerkstoffe, wie Titan und Titanlegierungen, ist AM bereits ein etabliertes Fertigungsverfahren und wird in der Luftfahrt, Medizintechnik, Automobil- und Schifffahrtindustrie für die Herstellung von zum Teil komplexen Bauteilen verwendet, die dann z. B. bei erhöhten Temperaturen und in korrosiven Medien eingesetzt werden [1]. Titanlegierungen werden in Abhängigkeit der Legierungselemente in $\alpha$ - , Near- $\alpha$-, $\alpha+\beta$ - und $\beta$-Legierungen eingeteilt [2] . Die am häufigsten eingesetzte Titanlegierung ist die $\alpha+\beta$-Legierung Ti-6Al-4V (m.\%) $[3,4]$. Bauteile daraus werden bspw. über das pulverbettbasierte selektive Laserschmelzen (engl.: Laser Powder Bed Fusion, LPBF) hergestellt. Dabei erstreckt sich die Materialcharakterisierung, vor dem Hintergrund der Qualitätssicherung von Prozess und Produkt, von metallischen Ausgangspulver bis hin zur additiv gefertigten dichten Materialprobe. Da die Qualität des Pulvers eng mit der Qualität des Endprodukts verknüpft ist, werden Parameter, wie die chemische Zusammensetzung, das Fließverhalten, die Klopf- und Fülldichte, die Sphärizität, der Porenanteil und die Partikelgrößenverteilung analysiert [5]. Bei der Untersuchung der additiv gefertigten Ti-6Al-4V Proben wird das Hauptaugenmerk auf mikrostrukturelle Charakteristika, wie z. B. Gefügehomogenität, Aussehen der hexagonalen (hex) martensitischen $\alpha^{\prime}$-Phase sowie auf die Phasenanteile gelegt [6, 7]. Durch den AM-Fertigungsprozess entstehen Gefügestrukturen, welche sich grundlegend vom 
classical melting metallurgy manufacturing processes. For instance, a layered structure with so-called "layer bands" is formed when Ti-6Al-4V is additively manufactured. This layered structure forms owing to segregations of the alloy constituents during the solidification process and the reaction of the surface with the ambient atmosphere and thus represents the molten pool boundaries of the manufacturing process $[8,9]$. This work also discusses how these layer structures are contrasted.

From a microstructural point of view, SLM manufactured $\alpha+\beta$ alloys, such as Ti$6 \mathrm{Al}-4 \mathrm{~V}$, exhibit an epitaxially $\beta$ solidification process through several applied layers inducing an anisotropic material behavior [8]. During the solidification process, the bodycentered cubic (bcc) $\beta$ phase, the high temperature phase of $\mathrm{Ti}$ and its alloys, is characterized by a preferred orientation in $\langle 100\rangle$ direction. Given that the size and shape of this columnar $\beta$ grain structure are a function of the SLM manufacturing parameters and subsequently impact on the component properties, it is particularly relevant to reveal this process-microstructure-property relationship. Knowing these relationships, SLM manufacturing parameters can be optimally adapted in order to achieve desired mechanical properties [8]. The $\beta$ grain structure formed from the melt in the epitaxial solidification process can either be visualized by etching (owing to the allotropic phase transformation $\left.\left(\beta \rightarrow \alpha^{\prime}\right)\right)$ or by reconstruction using a program-based process. The program-based back-calculation is based on data from backscatter diffraction experiments. The data analysis is, for instance, performed based on ARPGE data $[10,11]$ (Automatic Reconstruction of Parent Grains from EBSD).

Once the additive manufacturing processes completed, the component is most often klassischen schmelzmetallurgischen Herstellprozess unterscheiden. Beispielsweise kommt es bei der additiven Fertigung von Ti-6Al-4V zu sogenannten "Layer-Bands" bzw. zur Ausbildung einer schichtartigen Struktur. Diese Schichtstruktur entsteht durch Segregationen der Legierungsbestandteile während des Erstarrungsprozesses sowie der Reaktion der Oberfläche mit der Umgebungsatmosphäre und repräsentiert somit die Schmelzbadgrenzen des Fertigungsprozesses [8, 9]. Im Rahmen dieser Arbeit wird auf die Kontrastierung dieser Schichtstrukturen eingegangen.

Aus mikrostruktureller Sicht erstarren SLM gefertigte $\alpha+\beta$-Legierungen, wie z. B. Ti-6Al-4V, epitaktisch in Form der primären $\beta$-Phase über mehrere aufgebrachte Schichten, was zu anisotropen Materialverhalten führt [8]. Die kubisch raumzentrierte (krz) $\beta$-Phase, die Hochtemperaturphase des $\mathrm{Ti}$ und seiner Legierungen, zeigt beim Erstarrungsprozess eine Vorzugsorientierung in $\langle 100\rangle$-Richtung. Da Größe und Form dieser kolumnaren $\beta$-Kornstruktur von den SLM-Fertigungsparametern abhängen und in weiterer Folge die Bauteileigenschaften beeinflussen, ist das Erfassen dieser Prozess-Mikrostruktur-Eigenschaftsbeziehung von besonderer Bedeutung. Die Kenntnis dieser Beziehungen macht es möglich, optimale Einstellung der SLM Fertigungsparameter und dadurch der mechanischen Eigenschaften zu erzielen [8]. Die visuelle Darstellung der $\beta$-Kornstruktur, welche sich im epitaktischen Erstarrungsprozess aus der Schmelze bildet, ist aufgrund der allotropen Phasenumwandlung $\left(\beta \rightarrow \alpha^{\prime}\right)$ entweder über Ätzen, oder durch eine Rekonstruktion über eine programmbasierte Rückrechnung möglich. Die programmbasierte Rückrechnung basiert auf Daten aus Experimenten der Elektronenrückstreubeugung und die Auswertung erfolgt z.B. mit ARPGE $[10,11]$ (engl.: Automatic Reconstruction of Parent Grains from EBSD).

Nach Abschluss des additiven Fertigungsprozesses wird das Bauteil meist einem Nach- 
subjected to a post-processing step [12] Post-processing steps such as Hot Isostatic Pressing, HIP, can induce further changes to the microstructure within the component or in surface-near layers [13]. In order to analyze the effectiveness and efficiency of the additive manufacturing process and/or post-processing, the metallographic preparation for the respective material characterization must therefore imperatively take into account process-microstructure relationships.

Components made of titanium alloys are usually prepared in a multi-stage grinding and polishing process subsequent to which they are directly examined or etched. In this context, Kroll etching is a frequently applied method for revealing the microstructure of the castings and forgings [7, 14-17]. The suitability of this preparation technique for additively manufactured titanium components is assessed in this work and the optimization of the metallographic preparation along the process chain, from the powdery raw material to the additively manufactured component, is outlined taking the example of the two-phase alloy Ti-6Al-4V.

\section{Experimental Procedure}

The metallographic preparation was carried out on additively manufactured components made of gas-atomized titanium alloy powder Ti-6Al-4V, grade 23 ELI (Extra Low Interstitials). For comparison purposes, the powder's particle size determination was performed applying two different methods. In addition to dry screening with mesh widths of $100,63,40$, and $25 \mu \mathrm{m}$, a Sympatec HELOS laser diffraction spectrometer was used to determine the grain size. The chemical composition of the powder was determined by atomic emission spectroscopy for the elements $\mathrm{Al}$ (6.27 m.\%), V (3.9 m.\%), and Fe (0.2 m.\%), and by carrier gas hot extraction for the ele- bearbeitungsschritt, dem Postprocessing, unterzogen [12]. Das Postprocessing, wie z.B. heiß-isostatisches Pressen (engl:: Hot Isostatic Pressing, HIP), kann darüber hinaus Veränderungen der Mikrostruktur innerhalb des Bauteils oder in den randnahen Schichten hervorrufen [13]. Um die Effektivität und Effizienz des additiven Fertigungsprozesses bzw. des Prostprocessings zu analysieren, ist es daher unabdingbar, bei der metallographischen Präparation im Zuge der Materialcharakterisierung auf die Prozess-Mikrostrukturbeziehungen einzugehen.

In der Regel werden Bauteile aus Titanlegierungen über einen mehrstufigen Schleif- und Polierprozess präpariert und in weiterer Folge direkt untersucht oder geätzt. Die Ätzung nach Kroll ist dabei eine häufig angewandte Methode, um die Mikrostruktur der Guss- und Schmiedeteile zu visualisieren [7, 14-17]. Die Eignung dieser Präparationstechnik für additiv gefertigte Titanbauteile wird in dieser Arbeit beleuchtet. So wird am Beispiel der zweiphasigen Ti-6Al-4V-Legierung die Optimierung der metallographischen Präparation entlang der Prozesskette, beginnend vom pulverförmigen Ausgangsprodukt bis zum additiv gefertigten Bauteil, gezeigt.

\section{Experimentelles}

Die metallographische Präparation erfolgte an additiv gefertigten Bauteilen, hergestellt aus gasverdüstem Pulver der Titanlegierung Ti-6Al-4V Grade 23 ELI (engl.: Extra Low Interstitials). Die Partikelgrößenbestimmung des Pulvers erfolgte aus Vergleichszwecken mittels zweier unterschiedlicher Verfahren. Zusätzlich zu einer Trockensiebanalyse mit den Maschenweiten 100, 63, 40 und $25 \mu$ m wurde ein HELOS Laserbeugungsspektrometer der Fa. Sympatec GmbH zur Korngrößenbestimmung eingesetzt. Die Bestimmung der chemischen Zusammensetzung des Pulvers erfolgte mittels Atomemissionspektroskopie für die Elemente $\mathrm{Al}(6,27 \mathrm{~m} . \%), \mathrm{V}$ (3,9 m.\%) und Fe (0,2 m.\%) bzw. einer Trägergas-Heiß- 
ments $\mathrm{O}(0.083 \mathrm{~m} . \%)$ and $\mathrm{N}(0.0205 \mathrm{~m} . \%)$, respectively. To characterize the powder, the powder flowability was determined by measuring the flow rate (ASTM B964 [18]) using a Carney funnel, while the powder bulk density was measured according to ASTM B212 [19] using a Hall flow meter. The sphericity measurements were carried out using a Retsch Technology particle size analyzer CAMSIZER XT.

The samples for the test series were manufactured on an EOS machine of the type M290. SLM manufactured density cubes with the dimensions $22 \times 22 \times 25 \mathrm{~mm}^{3}$ were manufactured for the characterization of the microstructure. Not just the as-built condition, i. e. the condition immediately subsequent to the manufacturing process, but also a heat-treated variant was analyzed. The heat treatment was performed by applying temperatures ranging from $800{ }^{\circ} \mathrm{C}$ to $850{ }^{\circ} \mathrm{C}$ for $1-3$ hours in $\mathrm{Ar}$ atmosphere. Due to non-disclosure agreements, the exact parameters of the heat treatment must not be specified. The samples were cut in a cutting machine ATM Brillant 221 using a resin-bonded, abrasive diamond cut-off wheel of the type BOD13 (Struers). It should be noted here that more detailed information about the preparation methods and parameters can be found in the next chapter. Subsequent to the cutting process, the sample material was embedded using the Struers hot mounting press CitoPress-20. For the sample mounting process, we had the bakelite-based mounting resin PolyFast (Struers) and the Cu-based mounting compound ProbeMet (Buehler) at our disposal. Grinding and polishing of the mounted samples were performed on a semi-automatic grinding and polishing machine Struers Tegramin-30. The vibratory polishing machine VibroMet-2 was used in combination with a chemically resistant polishing cloth of the type MicroCloth (Buehler) for further polishing. Electrolytic polishing and etching steps were performed on a extraktion für die Elemente $\mathrm{O}(0,083 \mathrm{~m} . \%)$ und N (0,0205 m.\%). Im Zuge der Pulvercharakterisierung wurde die Pulver-Fließfähigkeit mittels Messung der Durchflussrate (ASTM B964 [18]) unter Verwendung eines Carney-Trichters bestimmt und die Pulver-Schüttdichte nach ASTM B212 [19] mit einem Hall-Flussmesser gemessen. Die Sphärizitätsmessungen erfolgten an einem Partikelmessgerät CAMSIZER XT der Fa. Retsch Technology GmbH.

Die Fertigung der Proben für die Versuchsreihe wurden an einer EOS-Maschine des Typs M290 vollzogen. Für die Mikrostrukturcharakterisierung wurden SLM gefertigte Dichtewürfel mit den Maßen $22 \times 22 \times 25 \mathrm{~mm}^{3}$ hergestellt. Neben dem as-built Zustand, d.h. direkt nach dem Fertigungsprozess, wurde auch eine wärmebehandelte Variante analysiert. Die Wärmebehandlung erfolgte in einem Temperaturbereich von $800^{\circ} \mathrm{C}-850^{\circ} \mathrm{C}$ für $1-3$ Stunden unter Ar-Atmosphäre. Die exakten Parameter der Wärmebehandlung dürfen aufgrund von Vertraulichkeitsvereinbarungen nicht angegeben werden. Der Zuschnitt der Proben erfolgte an einer Trennmaschine ATM Brillant 221 unter Verwendung einer harzgebundenen, abrasiv wirkenden Diamanttrennscheibe des Typs BOD13 der Fa. Struers. An dieser Stelle sei angemerkt, dass detaillierte Informationen der Präparationsmethoden und Parameter im nächsten Kapitel zu finden sind. Das Probenmaterial wurde im Anschluss an den Trennvorgang mit der Warmeinbettpresse CitoPress-20 der Fa. Struers eingefasst. Als Einbettmittel standen die kunststoffbasierte Variante Polyfast der Fa. Struers und die Cu-basierte Variante ProbeMet der Fa. Buehler zur Verfügung. Die Schleif- und Polierschritte der eingebetteten Proben erfolgte an einem semiautomatischen Schleif- und Polierautomat Tegramin-30 der Fa. Struers. Für weiteres Polieren wurde das Vibrationspoliergerät VibroMet-2 mit einem chemisch beständigen Poliertuch des Typs MicroCloth der Fa. Buehler verwendet. Die elektrolytischen Polier- sowie Ätzschritte erfolgten an einem Gerät vom Typ LectroPol-5 der Fa. Struers unter Verwendung der in Tab. 1 angeführten Elektrolyte. Des Weiteren sind im unteren Teil der Tabelle 
Struers LectroPol-5 machine using the electrolytes listed in Tab. 1. The lower part of the table also lists the etchants used to reveal the macro and microstructure. The present phases were also analyzed in X-ray diffraction experiments (XRD). For this purpose, a Bruker D8 Advance diffractometer was used in Bragg-Brentano geometry with a parallel beam configuration applying $\mathrm{Cu}-\mathrm{K}_{\alpha}$ radiation $(\lambda=1.54 \AA)$. The diffractograms were acquired using a Sol-X detector applying the following measurement parameters: step size of $0.02^{\circ}$, measuring time of $2 \mathrm{~s}$.

The light microscope examinations were performed on a Zeiss AXIO Imager.M2 light microscope (LM) equipped with an AxioCam HRc. 5 camera. A Versa 3D Dual Beam type FEl scanning electron microscope (SEM) with a field emission cathode and a auch die verwendeten Ätzmittel zur Darstellung der Makro- bzw. Mikrostruktur aufgelistet. Die Analyse der vorliegenden Phasen wurden auch mittels Röntgenbeugungsexperimente (engl.: X-Ray Diffraction, XRD) vorgenommen. Hierzu wurde ein Diffraktometer des Typs D8 Advance der Fa. Bruker in Bragg-Brentano-Anordnung und Parallelstrahl-Konfiguration eingesetzt, wobei mit Cu-K ${ }_{\alpha}$-Strahlung $(\lambda=1,54 \AA)$ gearbeitet wurde. Die Diffraktogramme wurden mit einem Sol-X Detektor aufgenommen, wobei als Messparameter eine Schrittweite von $0,02^{\circ}$ und eine Messzeit von $2 \mathrm{~s}$ eingestellt wurden.

Die lichtmikroskopischen Untersuchungen wurden am Lichtmikroskop (LM) des Typs AXIO Imager.M2, ausgestattet mit einer AxioCamHRc.5 Kamera der Fa. Zeiss, durchgeführt. Für hochauflösende Untersuchungen wurde ein Rasterelektronenmikroskop (REM) vom Typ

\begin{tabular}{|c|c|}
\hline Name & Composition / Zusammensetzung \\
\hline $\begin{array}{l}\text { Electrolyte A3 } \\
\text { (Struers) / Elektrolyt } \\
\text { A3 der Fa. Struers }\end{array}$ & $\begin{array}{l}\text { Mixture of methanol } \mathrm{CH}_{3} \mathrm{OH} \text { and 2-butoxyethanol / } \\
\text { Gemisch aus Methanol } \mathrm{CH}_{3} \mathrm{OH} \text { und 2-Butoxy-Ethanol }\end{array}$ \\
\hline $\begin{array}{l}\text { Electrolyte Ti Em3 / } \\
\text { Elektrolyt Ti Em3 }\end{array}$ & $\begin{array}{c}35 \mathrm{ml} \text { distilled water, } 60 \mathrm{ml} \text { methanol } \mathrm{CH}_{3} \mathrm{OH}-99.8 \%, 10 \mathrm{ml} \text { lac- } \\
\text { tic acid } \mathrm{C}_{3} \mathrm{H}_{6} \mathrm{O}_{3}-32 \%, 5 \mathrm{ml} \text { phosphoric acid } \mathrm{H}_{3} \mathrm{PO}_{4}-85 \%, 5 \mathrm{~g} \\
\text { citric acid } \mathrm{C}_{6} \mathrm{H}_{8} \mathrm{O}_{7} \text {, and } 5 \mathrm{~g} \text { oxalic acid } \mathrm{C}_{2} \mathrm{H}_{2} \mathrm{O}_{4}[31] / 35 \mathrm{ml} \text { des- } \\
\text { tilliertes Wasser, } 60 \mathrm{ml} \text { Methanol } \mathrm{CH}_{3} \mathrm{OH}-99,8 \%, 10 \mathrm{ml} \text { Milch- } \\
\text { säure } \mathrm{C}_{3} \mathrm{H}_{6} \mathrm{O}_{3}-32 \%, 5 \mathrm{ml} \text { Phosphorsäure } \mathrm{H}_{3} \mathrm{PO}_{4}-85 \%, 5 \mathrm{~g} \\
\text { Zitronensäure } \mathrm{C}_{6} \mathrm{H}_{8} \mathrm{O}_{7} \text { und } 5 \text { g Oxalsäure } \mathrm{C}_{2} \mathrm{H}_{2} \mathrm{O}_{4}[31]\end{array}$ \\
\hline $\begin{array}{l}\text { Wet etching according } \\
\text { to Kroll / Nassät- } \\
\text { zung nach Kroll }\end{array}$ & $\begin{array}{l}100 \mathrm{ml} \text { distilled water, } 2-6 \mathrm{ml} \text { nitric acid } \mathrm{HNO}_{3}-65 \% \text {, and } 1-3 \mathrm{ml} \\
\text { hydrofluoric acid } \mathrm{HF}-40 \% \text { [31] / } 100 \mathrm{ml} \text { destilliertes Wasser, 2-6 ml } \\
\text { Salpetersäure } \mathrm{HNO}_{3}-65 \% \text { und 1-3 ml Flusssäure } \mathrm{HF}-40 \% \text { [31] }\end{array}$ \\
\hline $\begin{array}{l}\text { Wet etching according } \\
\text { to Weck / Nassät- } \\
\text { zung nach Weck }\end{array}$ & $\begin{array}{l}100 \mathrm{ml} \text { distilled water, } 50 \mathrm{ml} \text { ethanol } \mathrm{C}_{2} \mathrm{H}_{5} \mathrm{OH}-50 \%, 2 \mathrm{~g} \text { ammoni- } \\
\text { um bifluoride } \mathrm{NH}_{4} \mathrm{HF}_{2}[31] / 100 \mathrm{ml} \text { destilliertes Wasser, 2-6 ml } \\
\text { Salpetersäure } \mathrm{HNO}_{3}-65 \% \text { und 1-3 ml Flusssäure HF-40\% [31] }\end{array}$ \\
\hline $\begin{array}{l}\text { Thermal etching } \\
\text { according to Barnes / } \\
\text { Thermische Ät- } \\
\text { zung nach Barnes }\end{array}$ & $\begin{array}{l}30 \text { and } 120 \text { min heat treatment at } 540^{\circ} \mathrm{C} \text {, respectively [29] / } \\
\text { Wärmebehandlung bei } 540^{\circ} \mathrm{C} \text { für } 30 \text { bzw. } 120 \text { min [29] }\end{array}$ \\
\hline
\end{tabular}

Tab. 1: List of the electrolytes used for electrolytic polishing and of etchants used to reveal the macro and microstructure.

Tab. 1: Auflistung der für das elektrolytische Polieren verwendeten Elektrolyte sowie die verwendeten Ätzmittel zur Sichtbarmachung der Makro- und Mikrostruktur. 
secondary electron detector was used for high resolution examinations. The electron backscatter diffraction (EBSD) measurements for a determination of the crystallographic structure and the orientation of the crystalline phases were also performed on the above-mentioned $\mathrm{FEl}$ device using a Hikari XP EBSD camera and an EDAX EBSD detector. Data were acquired and analyzed using the EDAX software OIM Data Collection and OIM Analysis 7 based on the following EBSD measurement parameters: accelerating voltage of $20 \mathrm{kV}$, step size of $100 \mathrm{~nm}$ and a $4 \times 4$ binning mode of the EBSD camera.

\section{Results and Discussion}

\subsection{Material Sampling and Mounting}

Fig. 1 shows the metallographic sample preparation workflow. In a first step, the sample material is taken. First, the powder is sampled. It should preferably be taken at several container positions. It is thus ensured that no individual powder fractions of a particular particle size are preferably examined, such as due to segregations.
Versa 3D Dual Beam der Fa. FEl unter Verwendung einer Feldemissionskathode und eines Sekundärelektronendetektors herangezogen. Die Elektronenrückstreubeugungs-Messungen (engl.: Electron Backscatter Diffraction, EBSD), zur Ermittlung der kristallographischen Struktur und Orientierung der kristallinen Phasen, erfolgten ebenfalls an dem zuvor erwähnten FEl-Gerät mittels einer EBSD-Kamera vom Typ Hikari XP und einem EBSD-Detektor der Fa. EDAX. Die Datenerfassung sowie -auswertung wurde mit der Software OIM Data Collection und OIM AnaIysis 7 der Fa. EDAX vorgenommen, wobei die Parameter der EBSD-Messung wie folgt waren: Beschleunigungsspannung $20 \mathrm{kV}$, Schrittweite $100 \mathrm{~nm}$ und ein 4×4 Binning Modus der EBSDKamera.

\section{Ergebnisse und Diskussion}

\subsection{Entnahme des Probenmaterials und Einbetten}

In Bild 1 ist der Verlauf der metallographischen Probenpräparation dargestellt. Der erste Schritt dabei ist die Entnahme des Probenmaterials. Beginnend beim Pulver sollte die Entnahme an mehreren Stellen des Behälters erfolgen. Hierdurch wird vermieden, dass bezüglich der Partikelgröße, z.B. aufgrund von Entmischungen, einzelne Pulverfraktionen bevorzugt untersucht werden.
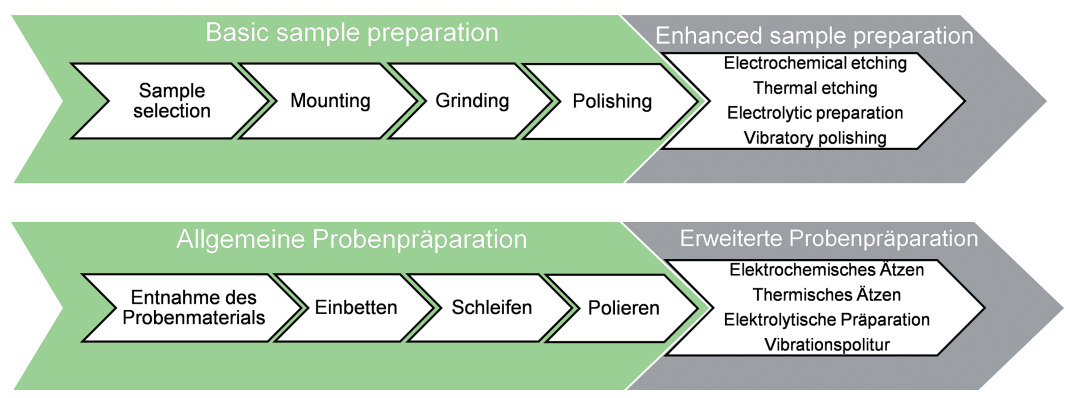

Fig. 1: Metallographic sample preparation workflow.

Bild 1: Verlauf der metallographischen Probenpräparation. 
Subsequent to the powder sampling process, the particles are characterized. For this purpose, particle size distribution, morphology, sphericity, flow rate, and bulk density are determined. In the diagram in Fig. 2, the cumulative powder particle distribution is plotted against the particle size. As is apparent from the diagram, there is a significant difference between the particle size distribution determined by laser diffraction and the distribution determined by sieve analysis. It should be taken into consideration that the sieve analysis was performed with a limited number of mesh sizes. As compared to the distribution obtained by laser diffraction-based particle sizing which allows for a finer gradation, this limited number of mesh sizes as well as sieve clogging by fine particles therefore resulted in a coarser distribution and over-estimated $d$ values $\left(d_{10}, d_{50}, d_{90}\right)$. Due to the mentioned problem, dry sieving should therefore be dispensed with for an examination of particles with a diameter of $<40 \mu \mathrm{m}$.

Fig. 3a) shows the powder particle morphology in a secondary electron SEM image. The SEM images reveal that the particles have a smaller fraction of satellites and
Im Anschluss an die Pulverentnahme erfolgt die Partikelcharakterisierung. Dazu werden Partikelgrößenverteilung, Morphologie, Sphärizität, Fließrate und Schüttdichte ermittelt. In dem in Bild 2 gezeigten Diagramm ist die Verteilungssumme der Pulverpartikel über der Partikelgröße aufgetragen. Es ist ersichtlich, dass ein deutlicher Unterschied zwischen der mit Laserdiffraktion und der mit Siebanalyse ermittelten Partikelgrößenverteilung gegeben ist. Zu beachten ist, dass die Siebanalyse mit einer limitierten Anzahl an Maschenweiten erfolgte. Diese limitierte Anzahl an Maschenweiten sowie das Verkleben der Siebe durch feine Partikel führten dazu, dass die Partikelgrößenverteilung im Vergleich zur Laserdiffraktion, bei der eine feinere Abstufung möglich ist, entsprechend gröber war und die ermittelten d-Werte $\left(d_{10}, d_{50}, d_{90}\right)$ überschätzt werden. Wegen der erwähnten Problematik sollte deshalb bei der Untersuchung von Partikel mit Durchmessern $<40 \mu \mathrm{m}$ davon abgesehen werden eine Trockensiebung durchzuführen.

Die Partikelmorphologie des Pulvers ist in Bild 3a) durch eine REM-Aufnahme im Sekundärelektronen-Modus dargestellt. Anhand der REM-Aufnahmen ist ersichtlich, dass die Par-

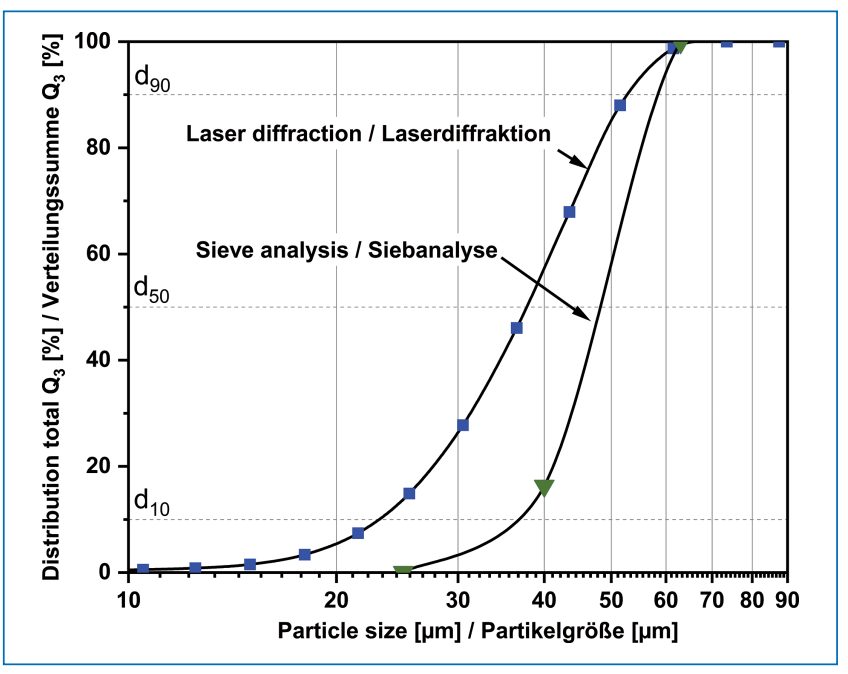

Fig. 2: Powder particle distribution results using two different analysis methods. The blue data points show the particle size distribution determined by laser diffraction. The green data points on a thin line illustrate the result of dry sieving (see text).

Bild 2: Ergebnis der Pulverpartikelverteilung mit zwei unterschiedlichen Analyseverfahren. Die blauen Datenpunkte zeigen die mittels Laserdiffraktion bestimmte Partikelgrößenverteilung. Die grünen Datenpunkte, verbunden mit einer dünnen Linie, stellen das Ergebnis aus der Trockensiebung dar (siehe Text). 
are very spherical which is reflected by a high sphericity value (0.95) according to ISO 9276 [20]. The bulk density of the powder is $2.49 \mathrm{~g} / \mathrm{cm}^{3}$. It thus amounts to $56 \%$ of the theoretical density of Ti-6Al-4V [21]. The Carney flow rate of the powder according to ASTM B964 [18] is $6.4 \mathrm{~s} / 50 \mathrm{~g}$.

\section{A metallographic section of the powder has} to be prepared for the purpose of examining any existing gas pores within the powder particles and for the structural analysis. As is apparent from Fig. 3b), individual powder particles may be removed during the metal powder mounting process (marked in red). To avoid this, it is recommended to either mix the metal powder particles with a sieved fine fraction $(<25 \mu \mathrm{m})$ of the mounting medium before mounting or to use a very fine mounting material with a low grain size. The use of a fine mounting material allows for reducing the fraction of removed powder particles.

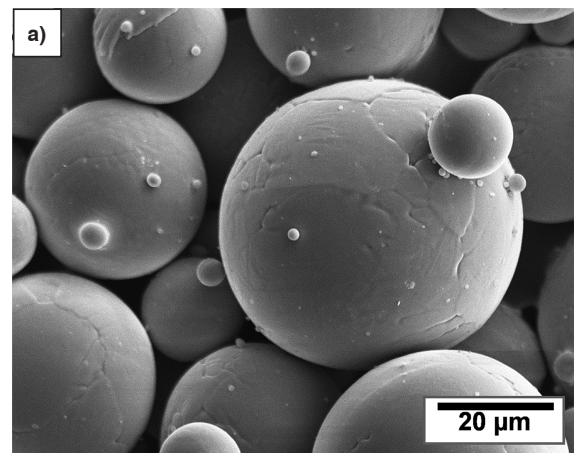

tikel einen geringen Satellitenanteil aufweisen und sphärisch sind, was sich in einem hohen Sphärizitätswert $(0,95)$ nach ISO 9276 [20] widerspiegelt. Die Schüttdichte des Pulvers beträgt 2,49 $\mathrm{g} / \mathrm{cm}^{3}$ und liegt somit bei $56 \%$ der theoretischen Dichte von Ti-6Al-4V [21]. Die Carney-Durchflussrate des Pulvers nach ASTM B964 [18] beträgt 6,4 s/50 g.

Für die Untersuchung von eventuell vorliegenden Gasporen im Inneren der Pulverpartikel sowie der Gefügeanalyse ist es nötig einen metallographischen Schliff des Pulvers anzufertigen. Wie in Bild 3b) gezeigt, kann es beim Einbetten des metallischen Pulvers zur Herauslösung einzelner Pulverpartikel kommen (in Rot markiert). Um dies zu vermeiden, ist es empfehlenswert, entweder das einzubettende Metallpulver vor dem Einfassvorgang mit einem gesiebten Feinanteil $(<25 \mu \mathrm{m})$ des Einbettmittels zu mischen oder ein sehr feines Einbettmittel mit einer geringen Korngröße zu verwenden. Durch die Verwendung eines feinen Einbettmittels kann der Anteil an herausgelösten Pulverpartikeln deutlich reduziert werden.

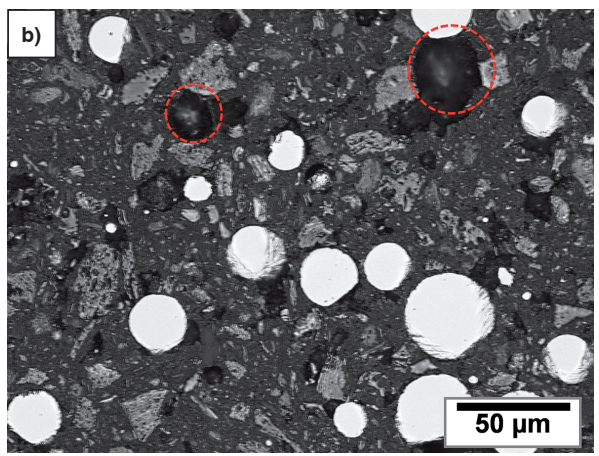

Figs. 3a and b: a) The SEM image (secondary electron mode) of the Ti-6Al-4V powder's particle morphology is characterized by very spherical shapes with a small proportion of satellites; $b$ ) LM image of the powder section, embedded in the bakelite-based mounting resin PolyFast. The dashed red circles mark positions where powder particles have been removed.

Bilder 3a und b: a) Die REM-Aufnahme (Sekundärelektronen-Modus) der Partikelmorphologie des Ti-6Al-4V Pulvers zeigt eine sphärische Form mit einem geringen Anteil an Satelliten; b) LM-Aufnahme des Pulverschliffs, eingebettet in das kunststoffbasierte Einbettmittel Polyfast. Die rot strichlierten Kreise markieren die Positionen, aus denen sich Pulverteilchen herausgelöst haben. 
The solid material samples are taken by sample cutting with the aid of abrasive cut-off wheels. They offer the advantage of being able to cut a wide range of materials and furthermore ensure a good surface quality after the cutting process [16]. However, in case of insufficient cooling or when the feed rate of the cut-off wheel is too high, the material may overheat. Such sample damages may lead to a misinterpretation of the microstructures and, once they have occurred, it is rather complicated to remove them. Sufficient cooling and the appropriate feed rate should therefore be ensured during the cut-off process. At a feed rate of $1 \mathrm{~mm} / \mathrm{min}$, it is appropriate to maintain a rotational speed of the cut-off wheel of 2500-3600 $\mathrm{min}^{-1}$. The used coolant should be composed of water, lubricant, and an anticorrosive agent additive. The additively manufactured solid material samples were either mounted in a bakelite mounting resin or a Cu-based mounting compound. The difference in hardness between the sample and the mounting medium is smaller using the Cu-based ProbeMet compound, thus allowing an enhanced mechanical preparation, including the surface layers. The examination of the surface and the surface layer is particularly important when analyzing additively manufactured components. During the electron microscope examination, the good electrical conductivity of copper additionally ensures a high and stable flow of secondary electrons (and thus a good contrast). However, longer curing times and higher acquisition costs are the drawbacks of this mounting material. For this work, the Cu-based mounting compound ProbeMet was used for SEM examinations. For all other examinations, the bakelite-based mounting resin was used. The sections were manufactured applying the following mounting press settings:
Die Entnahme der Vollmaterialproben erfolgt über einen Probenzuschnitt durch abrasiv wirkende Schneidscheiben. Diese bieten den Vorteil ein breites Spektrum an Werkstoffen trennen zu können und darüber hinaus eine gute Oberflächenqualität nach dem Trennprozess zu gewährleisten [16]. Bei unzureichender Kühlung oder durch einen zu hohen Vorschub der Trennscheibe kann es jedoch zum Überhitzen des Werkstoffs kommen. Während des Schneidvorgangs sollte daher stets auf eine ausreichende Kühlung sowie die richtige Vorschubgeschwindigkeit geachtet werden, da derartige Probenschädigungen nur sehr aufwendig wieder entfernt werden können bzw. zu Fehlinterpretationen des Gefüges führen können. Bei einer Vorschubgeschwindigkeit von $1 \mathrm{~mm} / \mathrm{min}$ ist es zweckmäßig eine Umdrehungsgeschwindigkeit der Trennscheibe von 2500-3600 $\mathrm{min}^{-1}$ einzuhalten. Das verwendete Kühlmittel sollte eine Mixtur aus Wasser, Schmiermittel und einem Korrosionsschutz in Form eines Additivs sein. Das Einbetten der additiv gefertigten Vollmaterialproben erfolgte entweder durch ein kunststoff- oder ein Cu-basiertes Einbettmittel. Bei der Verwendung des Cu-basierten ProbeMet ist der Härteunterschied zwischen Probe und Einbettmittel geringer, was eine bessere mechanische Präparation, auch im Bereich der Randschichten, ermöglicht. Gerade bei additiv gefertigten Bauteilen ist eine Oberflächen- und Randschichtuntersuchung von besonderer Bedeutung. Aufgrund der guten elektrischen Leitfähigkeit des Kupfers ist zusätzlich für einen hohen und stabilen Sekundärelektronenstrom (und damit einem guten Kontrast) im Zuge der elektronenmikroskopischen Untersuchung gesorgt. Nachteile dieses Einbettmittels sind jedoch eine höhere Aushärtezeit sowie höhere Materialkosten bei der Anschaffung. Im Zuge dieser Arbeit wurde für Untersuchungen im REM das Cu-basierte Einbettmittel ProbeMet verwendet. Für alle anderen Untersuchungen fand das kunststoffbasierte Einbettmittel seine Anwendung. Zur Herstellung der Schliffe wurden folgende Einstellungen an der Einbettpresse vorgenommen: 
- Bakelite mounting resin PolyFast: 3 minute heating phase at $180^{\circ} \mathrm{C}$ and 250 bar followed by 1.5 min water rinsing,

- Cu mounting compound ProbeMet: 7.5 minute heating phase at $180^{\circ} \mathrm{C}$ and 300 bar followed by 4.5 min water rinsing.

\subsection{Grinding and Polishing}

Subsequent to cutting and mounting, the sample preparation workflow involves a wet grinding and polishing step. The rough and deformed zone resulting from the cutoff process is unfavorable for the analysis. It is removed by plane grinding ensuring a plane-parallel sample surface $[16,17]$. Subsequently, successive fine grinding steps are performed using progressively finer grits. It should be taken into consideration here, that severe damages such as scratches, relief, break-offs, and cracks cannot be removed anymore in the following polishing steps $[16,17]$.

The dense, thin, and stable oxide layer on the surface with its high affinity for oxygen presents a challenge in the preparation of Ti alloys. Although it provides effective corrosion protection [22], it needs to be removed in the course of sample preparation. A chemical-mechanical polishing process is appropriate to suppress the formation of an oxide layer, especially during the last polishing steps. The formation of a surface layer is suppressed, i. e. the removal rate is increased and the formation of a cover layer is prevented by adding hydrogen peroxide $\mathrm{H}_{2} \mathrm{O}_{2}$ to the colloidal silicon dioxide $\mathrm{SiO}_{2}$ polishing suspension (OPS) [16, 23]. Tab. 2 shows the parameters of the grinding and polishing steps applied based on which reproducible results and an optimal metallographic sample preparation providing excellent surface quality could be achieved. The difference in hardness between the investment material and the sample and the thus generated sample elevation may provoke an undesired rocking motion of the sample
- Kunststoffeinbettmittel Polyfast: Heizphase bei $180{ }^{\circ} \mathrm{C}, 250$ bar für 3,0 min, gefolgt von 1,5 min Wasserspülung.

- Cu-Einbettmittel ProbeMet: Heizphase bei $180{ }^{\circ} \mathrm{C}, 300$ bar für 7,5 min, gefolgt von 4,5 min Wasserspülung.

\subsection{Schleifen und Polieren}

Nach dem Trenn- und Einbettvorgang stellen Nassschleifen und Polieren die nächsten Schritte der Probenpräparation dar. Während des Planschleifens wird die durch den Trennvorgang entstandene, aber für die Analyse ungeeignete, Rauigkeits- und Deformationszone entfernt und eine planparallele Oberfläche der Probe erzeugt $[16,17]$. Folgend werden aneinander gereihte Feinschleifschritte mit jeweils abnehmender Körnung des Schleifens durchgeführt. Es sollte dabei beachtet werden, dass schwerwiegende Schädigungen (Kratzer, Relief, Ausbrüche, Risse) in den nachfolgenden Polierschritten nicht mehr entfernt werden können [16, 17].

Eine Herausforderung bei der Präparation von Ti-Legierungen stellt aufgrund der hohen Affinität zu Sauerstoff die dichte, dünne und stabile Oxidschicht auf der Oberfläche dar. Diese Schicht ist ein effektiver Korrosionsschutz [22], muss jedoch im Rahmen der Probenpräparation abgetragen werden. Um die Bildung der Oxidschicht zu unterdrücken, ist speziell bei den letzten Polierschritten ein chemischmechanischer Poliervorgang zweckmäßig. Durch Zugabe von Wasserstoffperoxid $\mathrm{H}_{2} \mathrm{O}_{2}$ zu der kolloidalen Siliziumdioxid $\mathrm{SiO}_{2}$ Poliersuspension (OPS) wird die Deckschichtbildung auf der Oberfläche unterdrückt, d.h. die Abtragsrate erhöht sowie eine Schmierschichtbildung verhindert $[16,23]$. Tab. 2 zeigt die angewandten Parameter der Schleif- und Polierschritte, welche zu reproduzierbaren Ergebnissen und einer optimalen metallographischen Probenpräparation mit einer hervorragenden Oberflächenqualität führten. Durch den Härteunterschied zwischen Einbettmasse und Probe sowie der dadurch entstehenden Probenüberhöhung kann es im Schleifprozess 


\begin{tabular}{|c|c|c|c|c|c|c|}
\hline \multirow[b]{2}{*}{$\begin{array}{l}\text { Step / } \\
\text { Stufe }\end{array}$} & \multirow{2}{*}{$\begin{array}{c}\text { Grinding/ } \\
\text { polishing pad / } \\
\text { Schleif-/Polier- } \\
\text { auflage }\end{array}$} & \multirow[b]{2}{*}{$\begin{array}{l}\text { Time [min] / } \\
\text { Zeit [min] }\end{array}$} & \multirow[b]{2}{*}{$\begin{array}{l}\text { Force per } \\
\text { Sample [N] / } \\
\text { Kraft pro } \\
\text { Probe [N] }\end{array}$} & \multicolumn{2}{|c|}{$\begin{array}{l}\text { Rotational speed / } \\
\text { Drehgeschwindigkeit }\end{array}$} & \multirow{2}{*}{$\begin{array}{c}\text { Cooling/ } \\
\text { polishing } \\
\text { agent / } \\
\text { Kühl-/ } \\
\text { Poliermittel }\end{array}$} \\
\hline & & & & $\begin{array}{c}\text { Pad } \\
\text { [rpm] / } \\
\text { Auflage } \\
\text { [U/min] }\end{array}$ & $\begin{array}{c}\text { Sample } \\
\text { holder } \\
\text { [rpm] / } \\
\text { Probenhal- } \\
\text { ter [U/min] }\end{array}$ & \\
\hline 1 & $\begin{array}{l}\text { Diamond grinding } \\
\text { wheel MD-Piano } \\
220 \text { / Diamant- } \\
\text { schleifscheibe } \\
\text { MD-Piano } 220\end{array}$ & 03:00-04:00 & 40 & 300 & 150 & $\mathrm{H}_{2} \mathrm{O}$ \\
\hline 2 & $\begin{array}{l}\text { SiC paper \#1200 / } \\
\text { SiC-Papier \#1200 }\end{array}$ & $00: 15-00: 20$ & 40 & 140 & 150 & $\mathrm{H}_{2} \mathrm{O}$ \\
\hline 3 & $\begin{array}{l}\text { SiC paper \#2000 / } \\
\text { SiC-Papier \#2000 }\end{array}$ & $00: 15-00: 20$ & 40 & 140 & 150 & $\mathrm{H}_{2} \mathrm{O}$ \\
\hline 4 & $\begin{array}{l}\text { SiC paper \#2000 / } \\
\text { SiC-Papier \#2000 }\end{array}$ & $00: 15-00: 20$ & 40 & 140 & 150 & $\mathrm{H}_{2} \mathrm{O}$ \\
\hline 5 & $\begin{array}{l}\text { SiC paper \#2000 / } \\
\text { SiC-Papier \#2000 }\end{array}$ & $00: 15-00: 20$ & 40 & 140 & 150 & $\mathrm{H}_{2} \mathrm{O}$ \\
\hline 6 & $\begin{array}{l}\text { Polishing cloth } \\
\text { MD-Chem / Polier- } \\
\text { tuch MD-Chem }\end{array}$ & $\begin{array}{l}\text { up to / bis } \\
\text { zu 08:00 }\end{array}$ & 40 & 140 & 150 & $\begin{array}{l}\mathrm{OPS} / \mathrm{H}_{2} \mathrm{O}_{2} \\
90 \mathrm{ml}: 15 \mathrm{ml}\end{array}$ \\
\hline
\end{tabular}

Tab. 2: Metallographic sample preparation parameters using the grinding and polishing machine Struers Tegramin-30 with a fixed sample holder.

Tab. 2: Parameter der metallographischen Probenpräparation am Schleif- und Polierautomat Tegramin-30 der Fa. Struers unter Verwendung eines fixierten Probenhalters.

during the grinding process [24]. It is particularly important to counter these rocking motions. Therefore, after the mounting process, all sample surfaces to be ground were given a chamfered edge. The sample motion can further be reduced by firmly fixing all samples in a sample holder instead of using a non-fixing sample holder with single piston force transmission. However, it should be taken into consideration here, that, owing to the fact that an uneven force application can occur induced by the central contact pressure, at least three samples are prepared simultaneously when using a fixing sample holder. In the course of the preparation optimization process, the removal of scratches was also analyzed with regard to the rotational motion of the sample holder relative to zu einer unerwünschten Wippbewegung der Probe kommen [24]. Da es von besonderer Bedeutung ist diesen Wippbewegungen entgegenzuwirken, wurden alle Proben nach dem Einbettprozess an der Schleiffläche mit einer Randfase versehen. Eine weitere Reduktion der Probenbewegung ist möglich, indem anstelle eines nicht fixierenden Probenhalters mit Kraftübertragung über Einzelkolben, alle Proben in einem Probenhalter fest eingespannt werden. Es sollte aber dabei beachtet werden, dass durch Verwendung eines fixierenden Probenhalters mindestens drei Proben gleichzeitig präpariert werden, da es aufgrund des Zentralandruckes zu einer ungleichmäßigen Kraftauftragung kommen kann. Im Zuge der Präparationsoptimierung wurde auch die Kratzerentfernung im Hinblick auf die Relativdreh- 
the grinding and polishing pad. It was found that the deformation zone was smaller when sample holder and working disk work in synchronization than when they are configured in counter rotation. Synchronism of the sample and the working disk reduces the relative speed and simultaneously suppresses rocking motions of the sections.

As is shown in Tab. 2, the plastic bonded diamond grinding wheel MD-Piano 220 (Struers) was used in preparation step 1 to provide plane-parallelism and to ensure the flatness of the section's surface. As this procedure may take up to 4 minutes, it is advantageous to use a manually resharpenable grinding wheel. It ensures a consistent removal rate and causes less wear as compared to SiC paper. When using $\mathrm{SiC}$ paper, the material removal rate is significantly reduced within a very short time. Therefore, the grinding time was limited to 15 to 20 seconds for the preparation steps 2 to 5 , respectively. The last preparation step, step 6, is an OPS polishing process. For this procedure, a mixture of OPS and $\mathrm{H}_{2} \mathrm{O}_{2}$ with a ratio of $90 \mathrm{ml} \mathrm{OPS:15} \mathrm{ml} \mathrm{H}_{2} \mathrm{O}_{2}$ is applied to a chemically resistant polishing cloth (Struers). It may take up to 8 minutes to remove the deformation zone of step 5 by OPS polishing.

It is equally important to perform intermediate sample cleaning after each preparation step. This ensures that no particles dislodged from the roughness and deformation zone are transferred to the next preparation step and, as a result, damage the surface. The sample cleaning processes during the preparation were carried out by thoroughly washing the sample holder and the clamped samples with soap. Once the preparation steps are completed, it is appropriate to remove the metallographic samples from the sample holder in order to clean them in an ultrasonic bath, for instance in ethanol solution, for several minutes. Subsequent to the ultrasonic bath, highly volatile substances bewegung des Probenhalters zur Schleif- und Polierauflage untersucht. Es zeigte sich, dass durch Gleichlauf von Probenhalter und Arbeitsscheibe die Verformungszone geringer war als bei einer Schaltung im Gegenlauf. Durch den Gleichlauf von Probe und Arbeitsscheibe wird die Relativgeschwindigkeit reduziert und auch Wippbewegungen der Schliffe unterdrückt.

Wie in Tab. 2 dargestellt, wurde im Präparationsschritt 1 die kunststoffgebundene Diamantschleifscheibe MD-Piano 220 der Fa. Struers verwendet, um eine Planparallelität herzustellen und die Ebenheit der Schliffoberfläche zu gewährleisten. Da dieser Vorgang bis zu 4 Minuten dauern kann, ist der Einsatz einer manuell nachschärfbaren Diamantschleifscheibe von Vorteil. Diese sorgt für eine gleichbleibende Abtragsleistung bei einem geringeren Verschleiß im Vergleich zu SiC-Papier. Da der Materialabtrag bei Verwendung eines SiC-Papiers innerhalb kürzester Zeit signifikant abnimmt, wurde bei den Präparationsschritten 2 bis 5 die Zeit auf 15 bis 20 Sekunden begrenzt. Im letzten Präparationsschritt 6 erfolgte die Politur mittels OPS. In diesem Schritt wird ein OPS$\mathrm{H}_{2} \mathrm{O}_{2}$-Gemisch im Verhältnis $90 \mathrm{ml}$-OPS:15 ml$\mathrm{H}_{2} \mathrm{O}_{2}$ auf ein chemisch beständiges Poliertuch der Fa. Struers aufgebracht. Die Entfernung der Deformationszone aus Stufe 5 mit Hilfe der OPS-Politur kann bis zu 8 Minuten dauern.

Von besonderer Bedeutung ist darüber hinaus die Zwischenreinigung der Probe nach jedem Präparationsschritt. Durch diese wird vermieden, dass herausgelöste Partikel aus der Rauigkeits- und Deformationszone in den nächsten Präparationsschritt übertragen werden und so die Oberfläche schädigen. Die Probenreinigung während den Präparationsschritten wurde durch ein gründliches seifenbasiertes Waschen des Probenhalters und der eingespannten Proben sichergestellt. Am Ende der Präparationsschritte ist es sinnvoll die metallographischen Schliffe aus dem Probenhalter zu entfernen und in einem Ultraschallbad, z. B. in einer Ethanollösung, für wenige Minuten zu reinigen. Des Weiteren wird nach dem Ultraschallbad 
such as isopropyl or petroleum ether are furthermore applied to avoid the formation of drying artifacts on the final, glassy surface.

\section{Microstructural Examination by Light Microscopy}

In the SLM process, powder layers are selectively heated and molten. Once the molten pool is solidified, further cooling results in $\alpha$ lamellae growth at the $\beta$ grain boundaries from the moment of reaching the $\beta$-transus temperature. Given sufficient undercooling, a diffusion-less martensitic transformation to acicular $\alpha^{\prime}$ martensite takes place induced by Umklapp processes once the temperature falls below the martensite start temperature. Moreover, the repeated thermal cycles of the AM process lead to an epitaxial growth of the $\beta$ grains induced by the steep temperature gradient in the molten pool and the resulting lower nucleation rate, as is described in [6]. The aforementioned microstructure formation can be evidenced after the basic sample preparation. The crystallographic orientations of the material can be revealed as early as after preparation step 6 by using a polarization filter in the LM without recourse to specific surface-modifying methods such as for selective etching. Fig. 4a) is a LM image of an additively manufactured Ti-6Al-4V sample in the as-built condition using a polarization filter combined with increased light intensity. Not only the acicular $\alpha^{\prime}$ martensite structure, but also the former $\beta$ grain boundaries can be recognized (dashed lines). It is apparent that the columnar $\beta$ grains extend over several hundred micrometers in the build direction, BD.

\section{Pore Analysis}

Fig. 4b) presents a LM image of the surface of an as-built sample prepared for the pore durch Aufbringung von hochflüchtigen Substanzen, wie z. B. Isopropanol oder Petrolether, verhindert, dass sich Trocknungsartefakte auf der finalen, spiegelglatten Oberfläche bilden.

\section{Mikrostrukturuntersuchung mittels Lichtmikroskopie}

Durch den SLM-Herstellungsprozess werden Pulverschichten selektiv erwärmt und aufgeschmolzen. Nach der Erstarrung des Schmelzbades beginnen bei weiterer Abkühlung ab Erreichen der $\beta$-Transustemperatur an den $\beta$-Korngrenzen $\alpha$-Lamellen zu wachsen. Bei ausreichender Unterkühlung kommt es nach Unterschreiten der Martensit-Start-Temperatur durch Umklappprozesse zu einer diffusionslosen martensitischen Umwandlung in nadeligen $\alpha^{\prime}$-Martensit. Die wiederholten thermischen Zyklen des AM Prozesses führen darüber hinaus zu einem epitaktischen Wachstum der $\beta$-Körner, welches durch den steilen Temperaturgradient im Schmelzbad und der daraus resultierenden geringen Keimbildungsrate hervorgerufen wird, wie es in [6] beschrieben ist. Der Nachweis der soeben beschriebenen Gefügeentstehung ist bereits nach der allgemeinen Probenpräparation möglich. Ohne Anwendung von speziellen oberflächenverändernden Methoden, wie z. B. für eine selektive Ätzung, können bereits nach Präparationsschritt 6 durch den Einsatz eines Polarisationsfilters im LM die kristallographischen Orientierungen des Materials sichtbar gemacht werden. Bild 4a) zeigt eine LM-Aufnahme einer additiv gefertigten Ti-6Al-4V-Probe im as-built Zustand unter Verwendung eines Polarisationsfilters in Kombination mit einer erhöhten Lichtstärke. Neben der nadeligen $\alpha^{\prime}$-Martensitstruktur sind auch die ehemaligen $\beta$-Korngrenzen anhand der gestrichelten Linien erkennbar. Es ist ersichtlich, dass sich die kolumnaren $\beta$-Körner über mehrere hundert Mikrometer in Baurichtung (engl.: Build direction, BD) erstrecken.

\section{Porenanalyse}

Bild 4b) zeigt eine für die Porenanalyse präparierte Aufnahme der Oberfläche einer as-built 

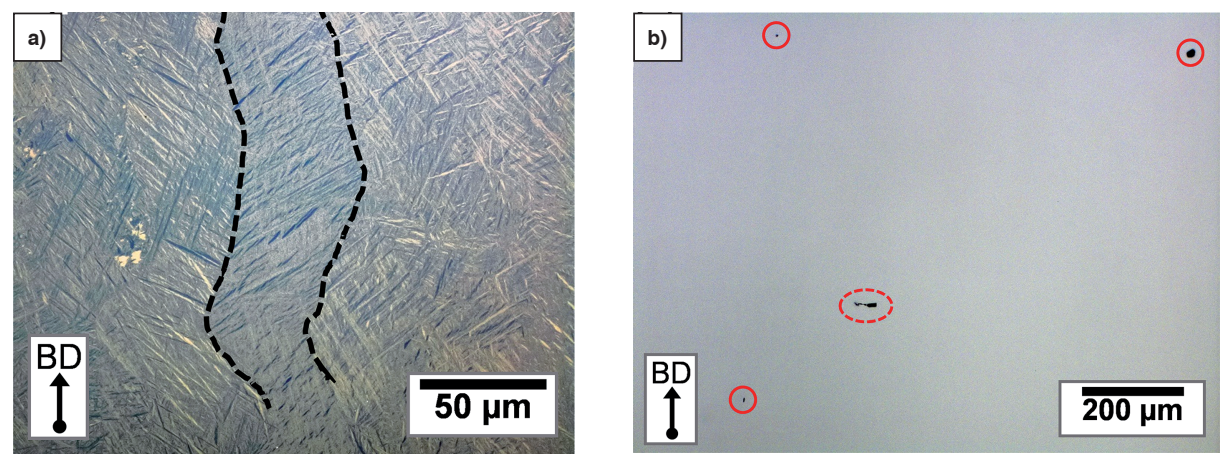

Figs. 4 a and b: a) Light microscope image of the martensitic microstructure of an additively manufactured Ti-6Al-4V sample in the as-built condition using a polarization filter. The dashed lines mark the epitaxial growth of a $\beta$ grain in the build direction (BD) of the SLM process; $b$ ) light microscope BF image of the sample surface used to determine the porosity. The circles with solid lines mark gas pores, while the dashed ellipse indicates a lack of fusion defect.

Bilder 4 a und b: a) Lichtmikroskopische Aufnahme der martensitischen Mikrostruktur einer additiv gefertigten Ti 6Al 4V-Probe im as-built Zustand unter Verwendung eines Polarisationsfilters. Die gestrichelten Linien markieren das epitaktische Wachstum eines $\beta$ Korns in Baurichtung BD des SLM Prozesses; b) Lichtmikroskopische HF-Aufnahme der Probenoberfläche zur Bestimmung der Porosität. Die durchgehenden Kreise markieren Gasporen, die gestrichelte Ellipse zeigt einen Anbindefehler.

analysis at a magnification of $200 \times$. Not only gas pores (continuous red circles), but also a lack of fusion defect (dashed red ellipse) could be detected in this sample during the $2 \mathrm{D}$ pore analysis. It is important to make sure the section's surface is dust-free, especially when determining the porosity in AM manufactured samples of a very high density (> 99.95\%), as otherwise the result may be distorted. In addition to that, a preferably large part of the surface should be considered and evaluated in order to ensure a statistically relevant result. The magnification for the LM images should not be less than $200 \times$ to ensure that smaller pores can be detected. The porosity was evaluated by phase fraction analysis using the software Olympus Stream Motion 1.9.3. The pores must additionally be manually sorted as a function of the surface area, and smaller pores $\left(<5 \mu \mathrm{m}^{2}\right)$ must be removed to avoid that pixels appearing dark are erroneously assigned to the pore fraction. By adhering to the mentioned process steps, a very precise
Probe im LM unter 200-facher Vergrößerung. Im Rahmen der 2D-Porenanalyse konnten bei dieser Probe neben Gasporen (durchgehende rote Kreise) auch Anbindefehler (gestrichelte rote Ellipse) detektiert werden. Speziell bei der Bestimmung des Porenanteils von AM gefertigten Proben, welche eine sehr hohe Dichte (>99,95\%) aufweisen, muss auf eine staubfreie Schlifffläche geachtet werden, da sonst das Ergebnis verfälscht werden kann. Des Weiteren sollte ein möglichst großer Anteil der Oberfläche erfasst und ausgewertet werden, um ein statistisch relevantes Ergebnis sicherzustellen. Die Vergrößerung bei den LM-Aufnahmen sollte nicht kleiner als 200 sein, um auch kleinere Poren detektieren zu können. Die Auswertung des Porenanteils erfolgte mittels Phasenanteilsanalyse der Software Olympus Stream Motion 1.9.3. Bei der Auswertung ist es überdies erforderlich, eine manuelle Sortierung von Poren als Funktion der Fläche durchzuführen und kleine Poren $\left(<5 \mu \mathrm{m}^{2}\right)$ zu entfernen, um zu verhindern, dass dunkel erscheinende Pixel fälschlicherweise den Poren- 
and reproducible porosity can be represented. In this work, a surface area of at least $100 \mathrm{~mm}^{2}$ covering different positions of the section represented in different images was accounted for during the pore analysis. For this purpose, a section from the center of the component was taken for examination. Care should be taken that the examined site is not located too near the component's edge, as, due to the high roughness in the edge areas, a non-representative porosity may be accounted for. A porosity of 0.028 vol.\% was measured for the as-built sample shown in Fig. 4b). By comparison, the heat-treated variant has an even lower porosity of 0.008 vol.\%, i.e. the sample is virtually completely dense.

\section{Phase Analysis}

One of the methods used to determine the phases and phase fractions, is the $\mathrm{X}$-ray diffraction examination. As it is a surface sensitive method, a deformed sample surface may lead to distorted measurement results and thus to misinterpretations. Turk et al. [25] showed that preparation-related residual compressive stresses induced by the grinding and polishing processes result in shifted and broadened XRD peaks. It is thus indispensable to ensure a deformation-free plane surface.

Fig. 5 shows an extract of XRD measurements performed on laser melted samples and on the powder sample. The solid material samples were treated following the preparation method presented in Tab. 2, removed from the mounting material, and analyzed. The powder samples were poured on a monocrystalline Si wafer plate for their examination and, as opposed to the solid material samples, the measurement was carried out without sample rotation. anteil zugerechnet werden. Bei Beachtung der erwähnten Verfahrensschritte ist es möglich, einen genauen und reproduzierbaren Porenanteil wiederzugeben. Im Zuge dieser Arbeit wurde durch mehrere Aufnahmen von unterschiedlichen Stellen des Schliffes, eine Fläche von mindestens $100 \mathrm{~mm}^{2}$ für die Porenanalyse erfasst. Es wurde dazu ein Schliff aus der Bauteilmitte für die Untersuchung herangezogen. Es ist zu beachten, dass die Untersuchte Stelle nicht zu nahe am Bauteilrand liegt, da es aufgrund der hohen Rauigkeit an den Randbereichen zu einem nicht repräsentativen Porenanteil kommen kann. Bei der in Bild 4b) gezeigten as-built Probe wurde ein Porenanteil von 0,028 vol.\% gemessen. Im Vergleich dazu weist die wärmebehandelte Variante einen noch geringeren Porenanteil von 0,008 vol.\% auf, d. h. eine nahezu vollständig dichte Probe liegt vor.

\section{Phasenanalyse}

Die Röntgenbeugungsuntersuchung ist eine Untersuchungsmethode, welche z. B. zur Bestimmung von auftretenden Phasen und Phasenanteilen eingesetzt wird. Da es sich hierbei um eine oberflächensensitive Methode handelt, kann eine verformte Probenoberfläche zu einer Verfälschung der Messergebnisse und somit zu einer Fehlinterpretation führen. Turk et al. [25] zeigte, dass präparationsbedingte Druckeigenspannungen, hervorgerufen durch den Schleif- und Polierprozess, zu einer Verschiebung und Verbreiterung der XRD-Peaks führen, wodurch unbedingt darauf geachtet werden muss, dass die Oberfläche verformungsfrei und plan ist.

In Bild 5 ist der Auszug aus XRD-Messungen an lasergeschmolzenen Proben sowie an der Pulverprobe dargestellt. Die Vollmaterialproben wurden nach der in Tab. 2 angegebenen Präparationsmethode behandelt und im ausgebetteten Zustand analysiert. Die Pulverproben wurden für die Untersuchung auf eine einkristalline Si-Waverplatte aufgeschüttet und die Messung erfolgte im Gegensatz zu den Vollmaterialproben ohne Probenrotation. 


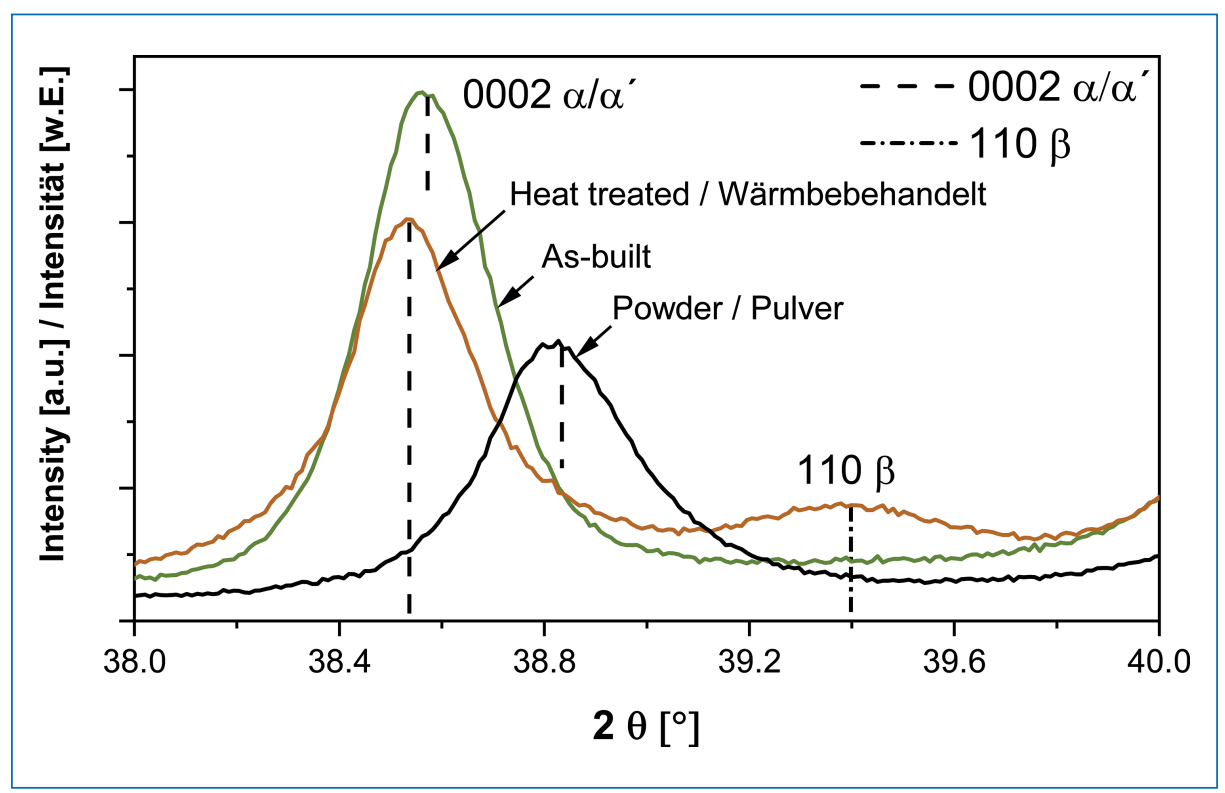

Fig. 5: XRD diffraction spectrum of the laser-melted samples and the examined powder indicating the angular range in which the $0002 \alpha / \alpha^{\prime}$ and the $110 \beta$ peak occur. The shift of the $\alpha / \alpha^{\prime}$ peak position (dashed line) from the powder sample to the heat-treated sample and the formation of the bcc $\beta$ phase (dash-dotted line) indicate a phase transformation $\left(\alpha^{\prime} \rightarrow \alpha+\beta\right)$ towards the thermodynamic equilibrium [7].

Bild 5: XRD-Beugungsspektren der lasergeschmolzenen Proben sowie des untersuchten Pulvers. Dargestellt ist der Winkelbereich, wo der $0002 \alpha / \alpha^{\prime}-$ und der $110 \beta$-Peak auftreten. Die Verschiebung der $\alpha / \alpha^{\prime}$-Peakposition (gestrichelte Linie) vom Pulver bis zur wärmebehandelten Probe und die Entstehung der krz $\beta$-Phase (strichpunktierte Linie) deuten auf eine Phasenumwandlung $\left(\alpha^{\prime} \rightarrow \alpha+\beta\right)$ in Richtung des thermodynamischen Gleichgewichts hin [7].

The obtained diffraction spectra show that the $\alpha / \alpha^{\prime}$ peaks (dashed peak position) are shifted from the powder samples to the heat-treated sample via the as-built sample. The diagram furthermore reveals that the bcc $\beta$ phase (dash-dotted position) occurs in the heat-treated condition. The shift of the hex 0002 peak and the precipitation of the $\beta$ phase are an indication of a phase transformation towards the thermodynamic equilibrium $\left(\alpha^{\prime} \rightarrow \alpha+\beta\right)$. The atomic radii of Al $(0.143 \mathrm{~nm})$ and $\mathrm{V}(0.132 \mathrm{~nm})$, smaller as compared to those of $\mathrm{Ti}(0.147 \mathrm{~nm})$, thus lead to an increasing $\alpha$ lattice parameter (decreasing $2 \theta$ angle) for an enrichment of $\checkmark$ in the $\beta$ phase [7].
Die erhaltenen Beugungsspektren zeigen, dass es zu einer Verschiebung des $\alpha / \alpha^{\prime}$-Peaks (gestrichelte Peakposition) von den Pulverproben über die as-built Probe bis zur wärmebehandelten Probe kommt. Darüber hinaus tritt im wärmebehandelten Zustand die krz $\beta$-Phase (strichpunktierte Position) auf. Die Verschiebung des hex 0002 Peaks sowie die Ausscheidung der $\beta$-Phase deuten auf eine Phasenumwandlung in Richtung des thermodynamischen Gleichgewichts $\left(\alpha^{\prime} \rightarrow \alpha+\beta\right)$ hin. Die kleineren Atomradien von $\mathrm{Al}(0,143 \mathrm{~nm})$ und V $(0,132 \mathrm{~nm})$ im Vergleich zu Ti $(0,147 \mathrm{~nm})$ führen dementsprechend bei Anreicherung von $V$ in der $\beta$-Phase zu einem größer werdenden $\alpha$-Gitterparameter (abnehmender 2 $\theta$-Winkel) [7]. 


\subsection{Enhanced Sample Preparation}

\section{Electrochemical Etching}

Electrochemical etching is a corrosive process generating a metallographic microstructural contrast based on a potential difference of different surface areas [26]. Potential differences occur owing to physical, structural, and chemical inhomogeneities such as those generated by the presence of multiple phases of varying density, with varying crystallographic orientations, or segregations [16]. At room temperature, the hex $\alpha$ phase and the bcc $\beta$ phase are present in the thermodynamic equilibrium in Ti-6Al-4V. A potential difference is already present here due to the different chemical compositions of these phases. An etchant frequently used for Ti-6Al-4V is the so-called Kroll's reagent. It contains hydrofluoric acid for a selective attack of the less noble Al-rich $\alpha$-phase, and nitric acid to brighten the surface [16]. The exact composition of Kroll's reagent is given in Tab. 1. Fig. 6 is a LM image of a lasermolten Ti-6Al-4V sample after ten-second Kroll etching. For the purpose of representing this 3D cube, three metallographic

\subsection{Erweiterte Probenpräparation}

\section{Elektrochemisches Ätzen}

Eine elektrochemische Ätzung ist ein korrosiver Prozess, in welchem durch eine Potentialdifferenz verschiedener Oberflächenbereiche eine metallographische Gefügekontrastierung generiert wird [26]. Potentialunterschiede entstehen durch physikalische, strukturelle und chemische Inhomogenitäten, wie z.B. durch Mehrphasigkeit unterschiedlicher Dichte, unterschiedliche kristallographische Orientierungen oder Seigerungen [16]. Im Fall von Ti-6Al-4V liegt bei Raumtemperatur im thermodynamischen Gleichgewicht sowohl die hex $\alpha$-Phase als auch die krz $\beta$-Phase vor. Hier besteht bereits ein Potentialunterschied aufgrund der unterschiedlichen chemischen Zusammensetzung dieser Phasen. Ein häufig eingesetztes Ätzmittel für Ti-6Al-4V ist die sogenannte Kroll-Ätzung. Dieses Reagenz enthält Flusssäure zum selektiven Angriff der unedleren, Al-reichen $\alpha$-Phase und Salpetersäure zum Aufhellen der Oberfläche [16]. Die genaue Zusammensetzung des Kroll-Ätzmittels ist in Tab. 1 angeführt. Bild 6 zeigt eine LM-Aufnahme einer lasergeschmolzenen Ti-6Al-4V-Probe nach einer 10-sekündigen

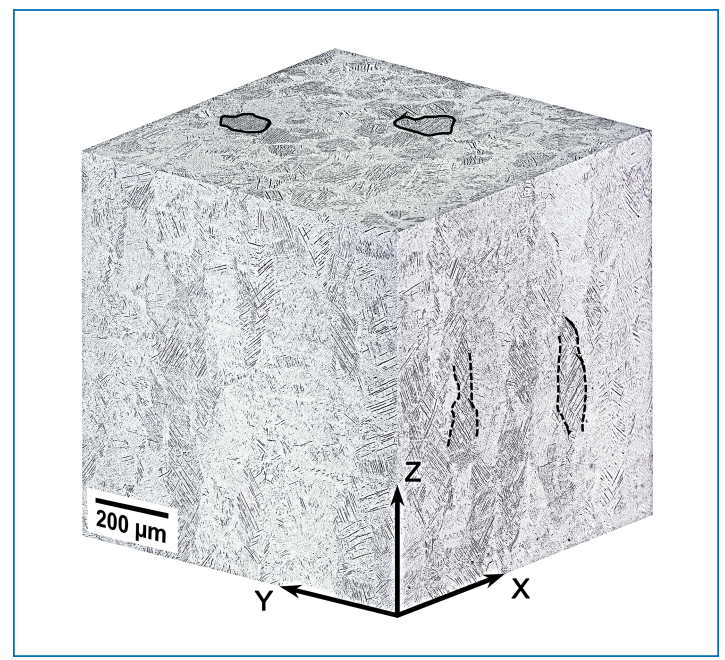

Fig. 6: Three-dimensional representation of a contrasted and laser-melted Ti-6Al-4V sample etched using Kroll's etching solution, acquired in the $L M$ (BF mode). The dashed lines indicate the epitaxial growth of a $\beta$ grain, while the black circles mark individual $\beta$ grains in the $X-Y$ cross section. The $Z$ direction represents the $B D$ of the SLM process.

Bild 6: Dreidimensionale Darstellung einer mit der Ätzlösung nach Kroll kontrastierten lasergeschmolzenen Ti-6Al-4V-Probe, aufgenommen im LM (HF-Modus). Die gestrichelten Linien zeigen das epitaktische Wachstum eines $\beta$-Korns und die schwarzen Kreise markieren einzelne $\beta$-Körner im $X-Y$-Querschnitt. Die Z-Richtung repräsentiert die BD des SLM Prozesses. 
sections were prepared, where the $Z$ axis represents the BD of the SLM process. This three-dimensional representation provides an overview of different areas of the additively manufactured components. The columnar grain structure (dashed lines) can be recognized in the $X-Z$ cross section, while the $\beta$ grain structure can be seen in the $X-Y$ cross section.

Another way of representing the microstructure is Weck's etching [27]. Figs. 7a-c) show the results of etching by immersion according to Weck. During the test series, it was found that an optimal microstructural contrast is achieved after a period of 35 seconds. Fig. 7a) shows the LM image (BF mode) of an as-built sample. This magnification reveals the layer structure (marked by black arrows). Owing to their different coloration, columnar grain structures (dashed lines) can also be observed normal to the BD. Fig. 7b) is a light microscope image of the same image detail at a higher magnification. It is apparent that this etching method provides an excellent contrast revealing the martensitic $\alpha^{\prime}$ needles.

In order to compensate the microstructural defects induced by the manufacturing process, components are subjected to a heattreatment or to HIP [28]. HIP reduces the porosity of the components and increases their density. Fig. 7c) shows the structure after Weck's etching of a heat-treated sample $\left(1-3\right.$ hours at $\left.800-850^{\circ} \mathrm{C}\right)$. Compared to the as-built sample, the needles appear broader, indicating a transformation of the martensite towards the thermodynamic equilibrium $\left(\alpha^{\prime} \rightarrow \alpha+\beta\right)$. The gray and black appearance of the $\alpha^{\prime}$ needles in Fig. 7c) indicates, moreover, that the needles belong to the former mother phase, the $\beta$ phase.
Kroll-Ätzung. Zur Darstellung dieses 3D-Würfels wurden drei metallographische Schliffe angefertigt, wobei die Z-Achse die BD im SLM-Prozess repräsentiert. Durch diese dreidimensionale Darstellung kann ein Überblick über verschiedene Bereiche des additiv gefertigten Bauteils geschaffen werden. Neben der kolumnaren Kornstruktur (gestrichelte Linien) im X-Z-Querschnitt ist auch die $\beta$-Kornstruktur im X-Y-Querschnitt zu erkennen.

Eine andere Möglichkeit um die Mikrostruktur abzubilden ist die Ätzmethode nach Weck [27]. Die Ergebnisse der Tauchätzung nach Weck sind in den Bilder $7 \mathrm{a}-\mathrm{c}$ ) dargestellt. Im Rahmen der Versuchsreihe zeigte sich, dass nach einer Dauer von 35 Sekunden die Mikrostruktur optimal kontrastiert wird. In Bild 7a) ist die LM-Aufnahme (HF-Modus) einer as-built Probe dargestellt. In dieser Vergrößerung sind die Schichtstruktur (markiert durch schwarze Pfeile) und, aufgrund unterschiedlicher Färbung, auch kolumnare Kornstrukturen (gestrichelte Linien) normal zur BD zu erkennen. Bild $7 b$ ) zeigt eine lichtmikroskopische Aufnahme desselben Bildausschnitts bei höherer Vergrößerung. Es ist zu erkennen, dass sich diese Ätzmethode durch eine deutliche Kontrastierung der martensitischen $\alpha^{\prime}$-Nadeln auszeichnet.

Um mikrostrukturelle Defekte, hervorgerufen durch den Herstellungsprozess, auszugleichen, werden Bauteile einer Wärmebehandlung oder HIP unterzogen [28]. Beim HIPen wird die Porosität des Bauteils reduziert und die Dichte erhöht. Des Weiteren ermöglicht HIPen die Minimierung des Anteils an geschlossenen Poren, welche durch Gaseinschlüsse entstehen. In Bild 7c) ist die Ätzung nach Weck an einer wärmebehandelten Probe (1-3 Stunden bei $800-850{ }^{\circ} \mathrm{C}$ ) gezeigt. Im Vergleich zur asbuilt Probe erscheinen die Nadeln breiter, was auf eine Umwandlung des Martensits in Richtung des thermodynamischen Gleichgewichts $\left(\alpha^{\prime} \rightarrow \alpha+\beta\right)$ hindeutet. Aufgrund der grau bzw. schwarz erscheinenden $\alpha^{\prime}$-Nadeln in Bild 7c) ist auch die Zugehörigkeit dieser zur ehemaligen Mutterphase, der $\beta$-Phase, zu erkennen. 

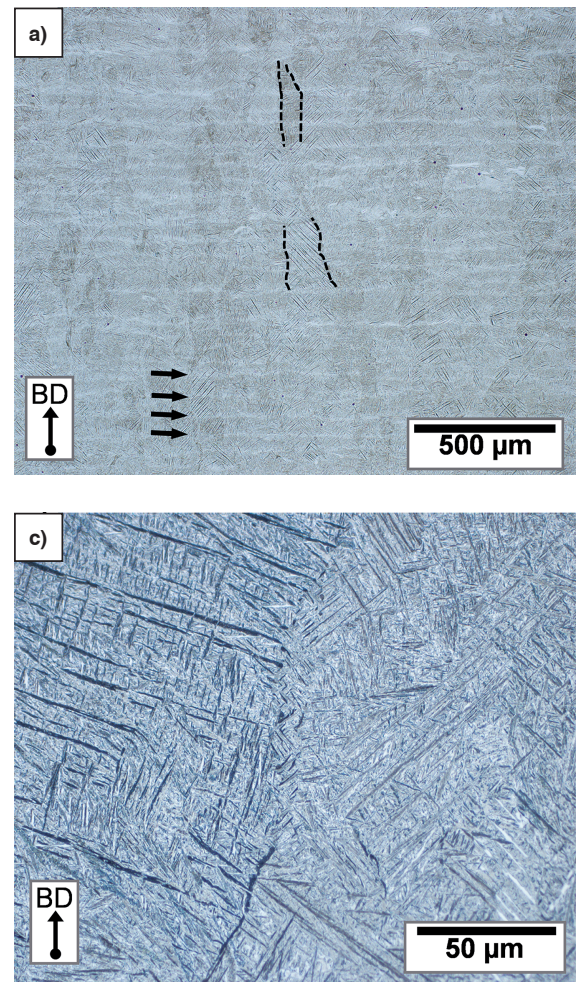

\section{Thermal Etching}

Another possibility to visualize the microstructure is a thermal etching process. During thermal etching, a physical etching method, an oxide layer is generated on the surface by elevated temperatures. In the LM, this layer appears in colors varying as a function of the present phases and their respective crystallographic orientation. The colors vary from brown (for shorter etching times) to red and blue (for longer etching times) [29]. Fig. 8 shows the result of a 120 min thermal etching process at $540{ }^{\circ} \mathrm{C}$ in air atmosphere. The image detail clearly shows the $\alpha$ needles. Given that elevated temperatures are required to generate the oxide layers, it must be noted at this point that thermal

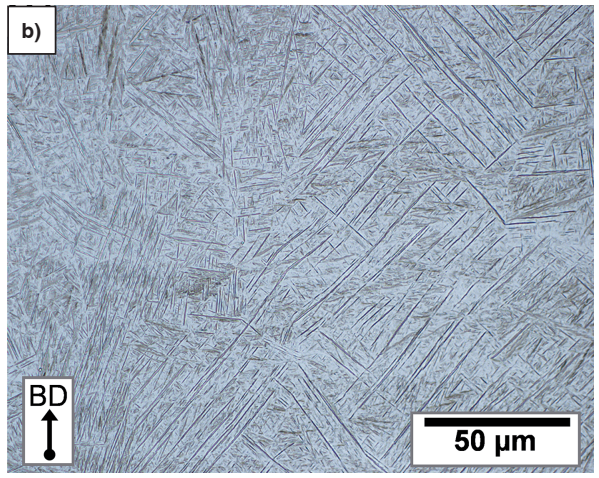

Figs. 7 a to c: Lightmicroscope image (BF mode) of the Ti-6Al-4V samples after Weck's etching at a) 50-fold and b) 500-fold magnification in the as-built condition and c) after heat treatment. The dashed lines in a) mark $\beta$ grain boundaries and the arrows indicate former molten pool boundaries normal to the BD of the SLM process.

Bilder 7 a bis c: Lichtmikroskopische Aufnahmen (HF-Modus) der Ti-6Al-4V-Proben nach einer Weck-Ätzung bei a) 50-facher und b) 500-facher Vergrößerung im as-built Zustand sowie c) nach einer Wärmebehandlung. Die gestrichelten Linien in a) markieren $\beta$-Korngrenzen und die Pfeile zeigen ehemalige Schmelzbadgrenzen normal zur $B D$ des SLM Prozesses an.

\section{Thermisches Ätzen}

Eine weitere Möglichkeit die Mikrostruktur zu visualisieren ist das Durchführen einer thermischen Ätzung. Bei dieser zu den physikalischen Ätzungen zählenden Methode, wird durch erhöhte Temperaturen eine Oxidschicht auf der Oberfläche erzeugt. Diese erscheint im LM in verschiedenen Farben in Abhängigkeit der auftretenden Phasen und deren kristallographischer Orientierung. Die Farben variieren dabei von braun bei kürzeren Ätzzeiten bis rot und blau bei längeren Ätzzeiten [29]. Das Ergebnis einer $120 \mathrm{~min}$ andauernden thermischen Ätzung unter Luftatmosphäre bei $540{ }^{\circ} \mathrm{C}$ wird in Bild 8 gezeigt. In diesem Bildausschnitt sind deutlich die $\alpha$-Nadeln zu erkennen. An dieser Stelle muss aber auch darauf hingewiesen werden, dass bei An- 
etching may, however, bring about microstructural changes.

\section{Electrolytic Preparation}

Owing to a an electric current flow between the sample (anode) and the counter electrode (cathode) and the use of an electrolyte, the surface is anodically dissolved during the electrolytic preparation. In addition, the potential difference results in precipitations and a varying surface layer thickness caused by the electrolyte $[26,30]$. Fig. 9 shows the results of an electrolytic sample preparation using the electrolyte Ti Em3 on an as-built component. Owing to the varying surface layer coverage, the columnar $\beta$ grain structure is particularly well contrasted applying a voltage of $100 \mathrm{~V}$ and a polishing time of $10 \mathrm{~s}$. As shown in Fig. 9a), it is also possible to capture a large number of $\beta$ grains, thus subsequently allowing a quantitative evaluation. The higher magnification of Fig. 9b) furthermore reveals the martensitic $\alpha^{\prime}$ needles, marked by arrows. They appear considerably brighter.

As opposed to anodic etching, where a surface layer is produced, a surface layer formation must be suppressed in case of a

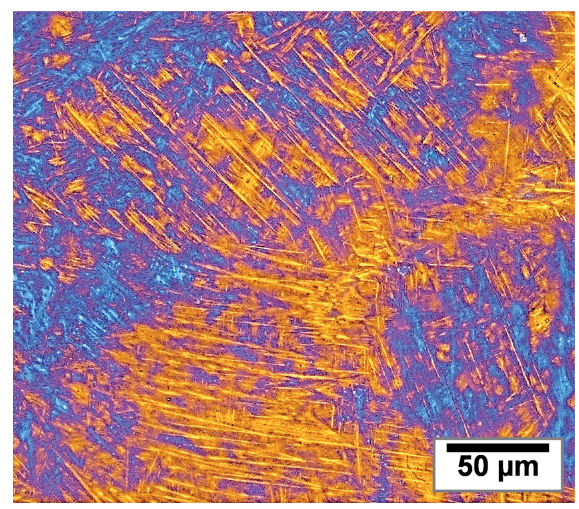

wendung einer thermischen Ätzung mikrostrukturelle Veränderungen auftreten können, da erhöhte Temperaturen zur Erzeugung der Oxidschichten notwendig sind.

\section{Elektrolytische Präparation}

Bei einer elektrolytischen Präparation wird aufgrund eines Stromes zwischen Probe (Anode) und Gegenelektrode (Kathode) und durch die Verwendung eines Elektrolyten die Oberfläche anodisch aufgelöst. Wird bei diesem Verfahren ein Elektrolyt verwendet, der zusätzlich zur Auflösung einen Niederschlag bzw. eine Deckschicht verursacht, werden aufgrund der Potentialunterschiede Kornflächen unterschiedlich stark belegt [26, 30]. Bild 9 zeigt eine elektrolytische Probenpräparation unter Verwendung des Elektrolyt Ti Em3 an einem as-built Bauteil. Bei Anlegung einer Spannung von $100 \mathrm{~V}$ und einer Polierzeit von $10 \mathrm{~s}$ kann durch die variierende Deckschichtbelegung besonders die kolumnare $\beta$-Kornstruktur kontrastiert werden. Wie aus Bild 9a) hervorgeht, ist es hierbei möglich, auch eine große Anzahl von $\beta$-Körnern zu erfassen, was in weiterer Folge eine quantitative Auswertung zulässt. Des Weiteren zeigt eine höhere Vergrößerung in Bild 9b) die martensitischen $\alpha^{\prime}$-Nadeln, angedeutet durch Pfeile, welche deutlich heller erscheinen.

Im Gegensatz zur anodischen Ätzung mit Deckschichtbildung muss bei der Präparation für die Elektronenrückstreubeugung eine

Fig. 8: Light microscope image (BF mode) of an additively manufactured Ti-6Al-4V sample thermally etched at $540{ }^{\circ} \mathrm{C}$ for 2 hours (see text).

Bild 8: Lichtmikroskopische Aufnahme (HF-Modus) einer bei $540^{\circ} \mathrm{C}$ für 2 Stunden wärmegeätzten additiv gefertigten Ti-6Al-4V-Probe, siehe Text. 

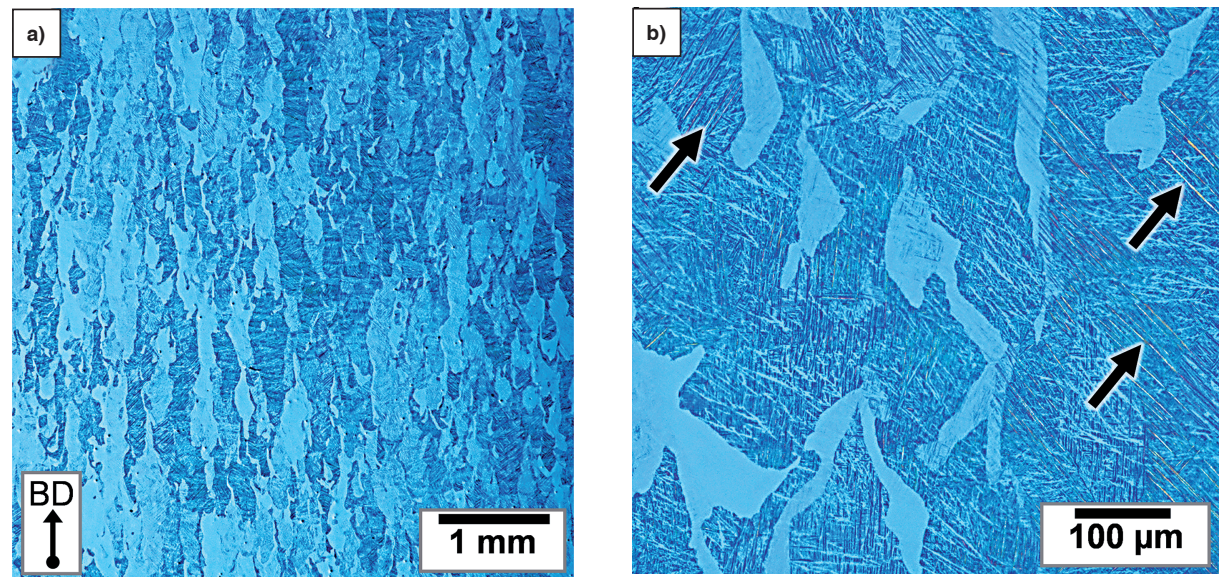

Fig. 9 a and b: Light microscope images in the BF mode: a) 25-fold and b) 200-fold magnification of an electrolytically polished as-built sample. The electrolyte Ti Em3 forms a surface layer as a function of the grain orientations. It is thus particularly suited to reveal the columnar $\beta$ grain structure, while also contrasting the martensitic $\alpha^{\prime}$ needles (see arrows).

Bilder 9 a und b: Lichtmikroskopische Aufnahmen im HF-Modus: a) 25-fache und b) 200-fache Vergrößerung einer elektrolytisch polierten as-built Probe. Der Elektrolyt Ti Em3 bildet eine Deckschicht in Abhängigkeit der Kornorientierungen und eignet sich daher besonders gut zur Visualisierung der kolumnaren $\beta$-Kornstruktur. Die martensitischen $\alpha^{\prime}$-Nadeln werden ebenfalls kontrastiert (siehe Pfeile).

preparation intended for electron backscatter diffraction, as the layer acts passively and impedes an emission of electrons from the surface. When samples are prepared for EBSD measurements, it should therefore be ensured that no surface layers are present on the surface and that the material removal process leaves a deformation-free surface [15]. Polishing parameters such as voltage, flow rate, and polishing time, were therefore varied aiming at improving the preparation result. Providing constant environmental conditions in the SEM such as sample type, accelerating voltage, sample current, and magnification, an average Confidence Index, $\mathrm{Cl}$, was determined for the respective EBSD measured area using the evaluation software OIM. The $\mathrm{Cl}$ indicates the level of accuracy of crystallographic orientation indexing. In this work, this value is used as a reference value to evaluate the preparation outcome. Given
Deckschichtbildung unterdrückt werden, da diese passiv wirkt und ein Austreten von Elektronen aus der Oberfläche erschwert. Bei der Probenvorbereitung für EBSD-Messungen sollte deshalb sichergestellt werden, dass die Oberfläche frei von Oberflächenschichten ist sowie eine durch den Materialabtrag geschaffene verformungsfreie Oberfläche entsteht [15]. In dieser Arbeit wurden deshalb gezielt Polierparameter, wie z.B. Spannung, Flussrate und Polierzeit, variiert, um das Präparationsergebnis zu verbessern. Bei gleichbleibenden Umfeldbedingungen im REM, wie Probentyp, Beschleunigungsspannung, Probenstrom und Vergrößerung, wurde mittels der Auswertesoftware OIM ein durchschnittlicher Vertrauensindex (engl.: Confidence Index, $\mathrm{Cl}$ ) für die jeweilige EBSD gemessene Fläche ermittelt. Der $\mathrm{Cl}$ ist ein Wert für die Richtigkeit der Indizierung einer kristallographischen Orientierung. In dieser Arbeit wird dieser Wert als Vergleichswert für den Präpa- 
the same environmental conditions, higher $\mathrm{Cl}$ values indicate a better sample surface quality. The preparation studies have shown that the best surface quality could be obtained using the electrolyte $A 3$ at a voltage of $30 \mathrm{~V}$ and a flow rate of 10 for a polishing time of $40 \mathrm{~s}$. The highest $\mathrm{Cl}$ values were reached based on these parameters for both, the as-built samples and the heat-treated samples.

\section{Vibratory Polish}

Apart from the described electrolytic preparation methods, it is also possible to prepare the surface of a sample for an EBSD measurement by subjecting it to a vibratory polish. However, in this case, the polishing rate is very low and the polishing process generally takes several hours [16]. For vibratory polishing, the mounted samples are clamped into a sample holder, thus providing the required contact pressure on the polishing disk. The holder is subsequently placed on a polishing cloth moistened with a polishing suspension and moved over the cloth by vibrations. For the vibratory polish, a chemically resistant MicroCloth polishing cloth (Buehler) was used in combination with an OPS. It was found that the highest $\mathrm{Cl}$ index for as-built samples was obtained after a polishing time of 8 hours. Owing to their lower hardness, the vibratory polishing time was reduced to 4 hours for the heattreated Ti-6Al-4V samples.

\section{EBSD Examinations}

Figs. 10 a) and b) show the grain orientation and the Image-Quality map (IQ) of an EBSD measurement on an as-built sample after 8 hours of vibratory polishing, respectively. The $Z$ axis of the EBSD coordinate system runs parallel to the BD. The martensitic microstructure's $\alpha^{\prime}$ needles and their crystallographic orientations can clearly be recognized, whereas, due to the heat-treat- rationserfolg herangezogen. Höhere $\mathrm{Cl}$-Werte stehen bei gleichen Umfeldbedingungen für eine bessere Qualität der Probenoberfläche. Die Präparationsstudien ergaben, dass mit dem Elektrolyt A3, unter Verwendung einer Spannung von $30 \mathrm{~V}$, einer Flussrate von 10 und einer Polierzeit von $40 \mathrm{~s}$, die beste Oberflächenqualität erreicht wurde. Sowohl die asbuilt als auch die wärmebehandelten Proben zeigten bei diesen Parametern die höchsten Cl-Werte.

\section{Vibrationspolitur}

Neben den beschriebenen elektrolytischen Präparationsmethoden besteht auch die Möglichkeit mit einer Vibrationspolitur die Oberfläche einer Probe für eine EBSD-Messung vorzubereiten. Die Polierrate ist aber sehr gering, was in der Regel zu Polierzeiten von mehreren Stunden führt [16]. Bei einer Vibrationspolitur werden eingebettete Proben in einem Probenhalter eingespannt, welcher für die nötige Anpresskraft auf die Polierscheibe sorgt. Der Halter wird anschließend auf ein mit Poliersuspension befeuchtetes Poliertuch aufgesetzt und durch Vibrationen über das Tuch bewegt. Für die Vibrationspolitur wurde ein chemisch beständiges Poliertuch vom Typ MicroCloth der Fa. Buehler in Kombination mit einer OPS verwendet. Es stellte sich heraus, dass bei as-built Proben nach einer Polierzeit von 8 Stunden der höchste $\mathrm{Cl}$-Index erreicht wurde. Bei den wärmebehandelten Ti-6Al-4VProben reduzierte sich die Vibrationspolierzeit auf 4 Stunden, da diese Proben eine geringere Härte aufweisen.

\section{EBSD-Untersuchungen}

Bilder 10 a) und b) zeigen die Kornorientierungs- und Qualitätsindex- (engl.: Image-Quality, IQ) Abbildung einer EBSD-Messung an einer as-built Probe nach einer Vibrationspolitur von 8 Stunden. Die Z-Achse des EBSDKoordinatensystems ist parallel zu BD. Es sind deutlich die $\alpha^{\prime}$-Nadeln der martensitischen Mikrostruktur und deren kristallographische Orientierungen zu erkennen. Im Vergleich dazu 

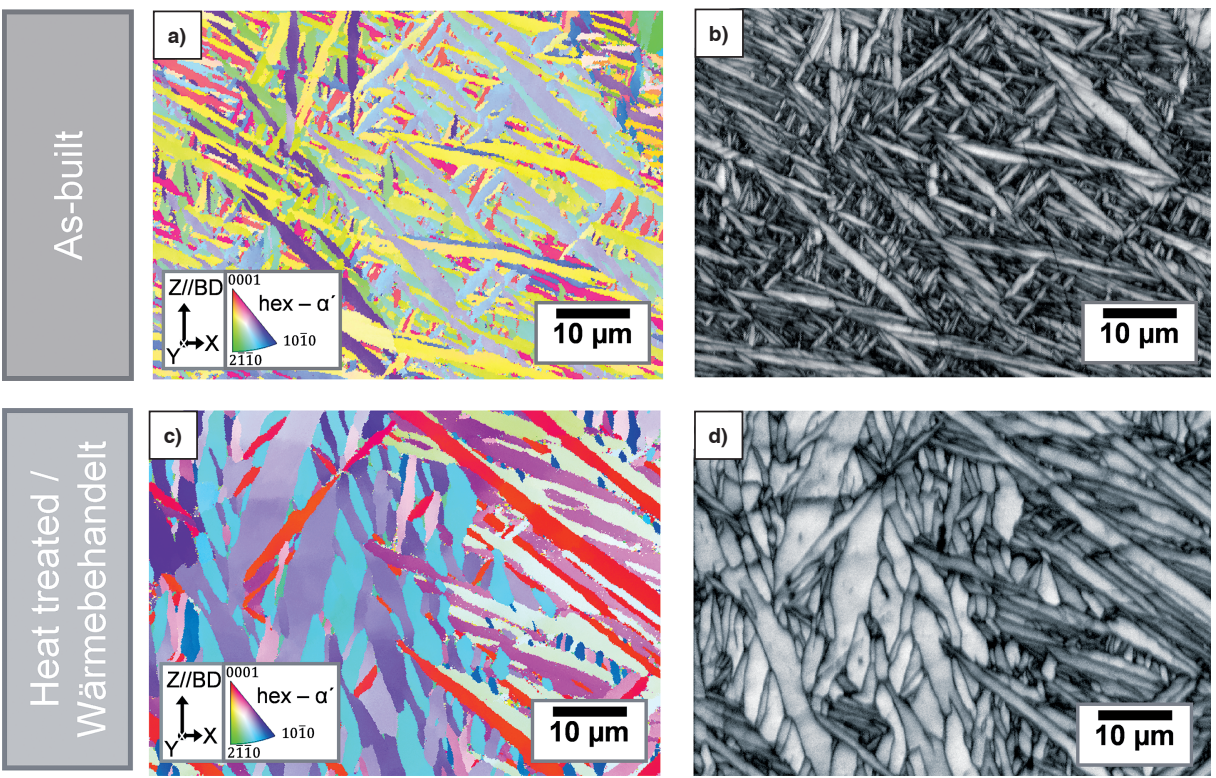

Figs. 10 a to d: EBSD grain orientation image of a a) martensitic and c) heat-treated Ti-6Al-4V sample with respective color coding according to the inverse pole figure; $b$ ) and d): EBSD IQ image (image quality index) of the same image sections.

Bilder 10a bis d: EBSD-Kornorientierungsabbildung einer a) martensitischen und c) wärmebehandelten Ti 6Al 4V-Probe mit der zugehörigen Farbkodierung gemäß der inversen Polfigur; b) und d): EBSDQualitätsindexabbildung (IQ) derselben Bildausschnitte.

ment, the microstructure in the figs. $10 \mathrm{c}$ ) and d) appears considerably coarser suggesting a temperature-induced grain growth. As opposed to the grain interior presenting higher values, the areas in the IQ images appearing darker are grain boundaries with low $\mathrm{Cl}$ values. The heat treatment induced low $\beta$ phase fraction ( $<5$ vol.\%) is located at the $\alpha$ grain boundaries. As the fraction is too low and the spatial resolution of the EBSD measurement is insufficient, it cannot be imaged.

Applying the optimized sample preparation procedure, it is now also possible to perform EBSD measurements of larger areas. Fig. 11 shows the result of an EBSD measurement of a heat-treated sample after 4 hour vibra- erscheint die Mikrostruktur durch die Wärmebehandlung in den Bildern 10 c) und d) deutlich gröber, was auf ein Kornwachstum aufgrund der verwendeten Temperatur schließen lässt. Die dunklen Bereiche in den IQ-Abbildungen sind Korngrenzen, an denen die Cl-Werte, im Gegensatz zum Korninneren, gering sind. Der durch die Wärmebehandlung entstandene geringe $\beta$-Phasenanteil ( $<5$ vol.\%) befindet sich an den $\alpha$-Korngrenzen und kann aufgrund des geringen Anteils und einer zu geringen Ortsauflösung der EBSD Messung bildlich nicht erfasst werden.

Durch die optimierte Probenpräparation ist es nun möglich, auch EBSD-Messungen an größeren Bereichen durchzuführen. Bild 11 zeigt das Ergebnis einer EBSD-Messung einer wärmebehandelten Probe nach einer Vi- 

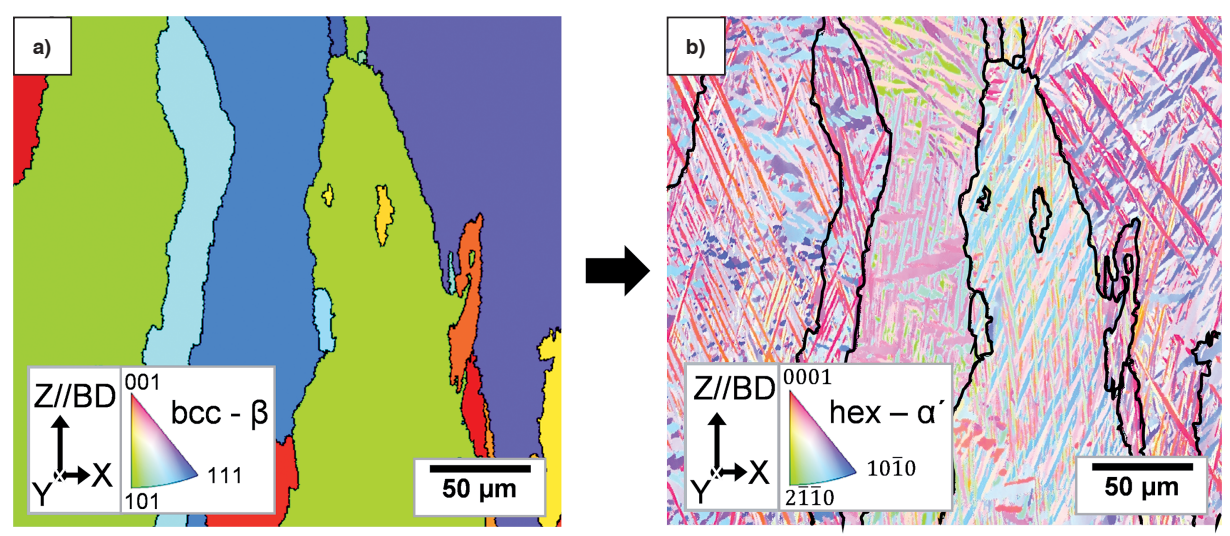

Figs. 11 a and b: a) $\beta$ grain structure of a heat-treated Ti-6Al-4V sample with $Y$ orientation calculated using the software ARPGE $[10,11]$; b) superposition of the calculated $\beta$ grain structure and the respective $E B S D$ grain orientation image indicating the respective orientation legends.

Bilder 11 a und b: a) Mit der Software ARPGE [10, 11] berechnete $\beta$-Kornstruktur einer wärmebehandelten Ti-6Al-4V-Probe mit Y-Ausrichtung; b) Überlagerung der berechneten $\beta$-Kornstruktur mit der zugehörigen EBSD-Kornorientierungsabbildung und der entsprechenden Orientierungslegenden.

tory polishing. As is apparent in Fig. 11a), the columnar $\beta$ grain structure could be reconstructed based on the so-called Burger's orientation relationship using the software ARPGE $[10,11]$. b) presents a superposition of the ARPGE file and the original file. This superposition reveals the $\beta$ grain structure in the EBSD grain orientation image. In this way, not only an image detail can be examined. Crystallographic information of individual $\beta$ grains can also be obtained by singling out and cutting along grain boundaries.

\section{Conclusions}

In this work, the sample preparation process for additively manufactured Ti-6AI-4V components was fundamentally analyzed. With this in mind, the entire process chain, from the preparation of powder samples to the sample preparation of SLM manufactured components, was outlined. An optimized sample preparation not just allows stand- brationspolitur von 4 Stunden. Wie in Bild 11a) ersichtlich, konnte mit der Software ARPGE $[10,11]$ über die sogenannte Burgers Orientierungsbeziehung die kolumnare $\beta$-Kornstruktur rekonstruiert werden. In b) ist eine Überlagerung der ARPGE-Datei mit der Ursprungsdatei dargestellt. Durch diese Überlagerung wird die $\beta$-Kornstruktur in der EBSD-Kornorientierungsabbildung visualisiert. Diese Darstellung ermöglicht es nun, neben der Untersuchung eines Bildausschnittes, durch Herausheben und Zuschnitt entlang von Korngrenzen auch kristallographische Informationen über einzelne $\beta$-Körner zu erhalten.

\section{Schlussfolgerungen}

In dieser Arbeit wurde grundlegend die Probenpräparation für additiv gefertigte Ti-6Al-4V-Bauteile untersucht. Hierfür wurde die gesamte Prozesskette, beginnend bei der Präparation von Pulverproben bis hin zur Probenvorbereitung von SLM-gefertigten Bauteilen, beleuchtet. Eine optimierte Probenpräparation ermöglicht, neben den 
ard examinations by LM and SEM. It also permits further crystallography investigations by EBSD of additively manufactured components. The preparations carried out on Ti-6Al-4V powder samples and AM components defined in this work lead to the following findings:

- During mounting, the hardness difference between a SLM manufactured solid material sample and the mounting material should be minimal in order to ensure an optimal preparation including the surface layer.

- The parameters listed in Tab. 2 allowed the manufacture of reproducible sections providing an excellent surface quality - a requirement and thus a precondition for a variety of examination methods.

- The $\beta$ grain structures formed during the SLM process based on which the microstructural evolution can be interpreted can be contrasted by selective etching or electrolytic preparation methods. Another possibility to reveal the $\beta$ grains is using a polarization filter in the LM.

- Specific etching processes, such as etching by immersion according to Weck, do not only reveal the microstructure. They also visualize the layer structure and the molten pool boundaries in the SLM manufactured components.

- High-resolution EBSD analyses presuppose an artifact and a deformation-free surface. Not only electrolytic polishing, but also vibratory polishing can be carried out to ensure a sufficient surface quality.

- Superposing numerically calculated $\beta$ grain structures and EBSD measurement data allows a targeted examination of the crystallography of individual $\beta$ grains.
Standarduntersuchungen mittels LM und REM, weiterführende Untersuchungen der Kristallographie mittels EBSD an additiv gefertigten Bauteilen durchzuführen. Die in dieser Arbeit definierten Präparationen an Ti-6Al-4V Pulverproben sowie AM-Bauteilen führten zu folgenden grundlegenden Erkenntnissen:

- Beim Einbetten von SLM-gefertigtem Vollmaterial sollte der Härteunterschied zwischen der Probe und dem Einbettmittel minimal sein, um eine optimale Präparation bis zur Randschicht zu ermöglichen.

- Mit dem in Tab. 2 beschrieben Verfahren konnten durchwegs reproduzierbar Schliffe mit hervorragender Oberflächenqualität hergestellt werden, was für eine Vielzahl von Untersuchungsmethoden notwendig ist und daher eine Voraussetzung ist.

- Die zur Interpretation der Gefügeentwicklung während des SLM-Prozesses entstehenden $\beta$-Kornstrukturen können mittels selektiven Ätzungen oder elektrolytischen Präparationsmethoden kontrastiert werden. Eine weitere Möglichkeit, die $\beta$-Körner zu visualisieren, ist die Verwendung eines Polarisationsfilters im LM.

- Mit speziellen Ätzungen, wie z.B. der Tauchätzung nach Weck, werden neben der Mikrostruktur auch die Schichtstruktur bzw. die Schmelzbadgrenzen in den SLMgefertigten Bauteilen sichtbar.

- Hochauflösende EBSD-Analysen setzen eine artefakt- und deformationsfreie Oberfläche voraus. Neben einer elektrolytischen Politur kann auch durch eine Vibrationspolitur für eine ausreichende Oberflächenqualität gesorgt werden.

- Die Überlagerung von numerisch berechneten $\beta$-Kornstrukturen mit EBSD-Messdaten ermöglicht es, die Kristallographie einzelner $\beta$-Körner gezielt zu untersuchen. 


\section{References / Literatur}

[1] DebRoy, T.; Wei, H.L.;Zuback, J.S.; Mukherjee, T.; Elmer, J.W.; Milewski, J.0.; Beese, A.M.; Wilson-Heid, A.; De, A.; Zhang, W.: Prog. Mater. Sci. 92 (2018), 112-224

DOI: 10.1016/j.pmatsci.2017.10.001

[2] Peters, M.; Leyens (Eds.), C.: Titanium and Titanium Alloys: Fundamentals and Applications, John Wiley \& Sons, 2003

DOl: $10.1002 / 3527602119$

[3] Uhlmann, E.; Kersting, R.; Klein, T.B.; Cruz, M.F.; Borille, A.V.: Procedia Cirp. 35 (2015), 55-60

DOI: 10.1016/j.procir.2015.08.061

[4] Barriobero-Vila, P.: Phase transformation kinetics during continuous heating of $\alpha+\beta$ and metastable $\beta$ titanium alloys, PhD Thesis, TU Vienna, Austria, 2015

[5] Wimler, D.; Kardos, S.; Lindemann, J.; Clemens, H.; Mayer, S.: Pract. Metallogr. 55 (2018), 620-636

DOI: $10.3139 / 147.110547$

[6] Frazier, W.E.: J. Mater. Eng. Perform. 23 (2014), Nr. 6, 1917-1928

DOI: 10.1007/s11665-014-0958-z

[7] Ter Haar, G.; Becker, T.: Materials. 11 (2018), Nr. 1, 146

DOI: $10.3390 / \mathrm{ma11010146}$

[8] Liu, S.; Shin, Y.C.: Mater. Des. 164 (2019), 107552

DOI: 10.1016/j.matdes.2018.107552

[9] Neikter, M.;Huang, A.;Wu,X.:Int.J.Adv. Manuf. Technol. 104 (2019), Nr. 1-4, 1381-1391 DOI: 10.1007/s00170-019-04002-8

[10] Cayron, C.: J. Appl. Crystallogr. 40 (2007), Nr. 6, 1183-1188

DOI: 10.1107/S0021889807048777

[11] Cayron, C.; Artaud, B.; Briottet, L.: Mater. Charact. 57 (2006), Nr. 4-5, 386-401 D0I: 10.1016/j.matchar.2006.03.008

[12] Lachmayer, R.; Lippert, R.B.: Additive Manufacturing Quantifiziert, Springer-Verlag, Berlin, 2017

DOI: 10.1007/978-3-662-54113-5

[13] Neikter, M.; Åkerfeldt, P.; Pederson, R.; Antti, M.L.: Microstructure characterisation of Ti-6Al-4V from different additive manufac- turing processes, in: IOP Conf. Ser. Mater. Sci. Eng., IOP Publishing, 2017

DOI: 10.1088/1757-899X/258/1/012007

[14] Wimler, D.; Lindemann, J.; Gammer, C.; SpoerkErdely, P.; Stark, A.; Clemens, H.; Mayer, S.: Mater. Sci. Eng. A. 792 (2020), 139798 DOI: 10.1016/j.msea.2020.139798

[15] Vander Voort, G.F.: Pract. Metallogr. 48 (2011), 527-543 DOI: 10.3139/147.110151

[16] Vander Voort, G.F.: Metallography, principles and practice, ASM International, New York, 1999

[17] Vander Voort, G.F.: Metallographic preparation of titanium and its alloys, in: Buehler Tech-Notes 3, Nr. 3, 1999

[18] ASTM B964-16: Standard Test Methods for Flow Rate of Metal Powders Using the Carney Funnel, 2016

[19] ASTM B212-17: Standard Test Method for ApparentDensity of Free-Flowing Metal Powders Using the Hall Flowmeter Funnel, 2017

[20] DIN ISO 9276: Darstellung der Ergebnisse von Partikelgrößenanalysen: Deskriptive und quantitative Darstellung der Form und Morphologie von Partikeln, 2012

[21] Tang, H.P.; Qian, M.; Liu, N.; Zhang, X.Z.; Yang, G.Y.; Wang, J.: JOM. 67 (2015), Nr. 3, 555-563 DOI: 10.1007/s11837-015-1300-4

[22] Lütjering, G.; Williams, J.C.: Titanium, 1st ed., Springer Science \& Business Media, 2007

[23] Siemers, C.: Maschinenbau. 5 (2013), 44-46, Olympia Verlag, Zürich, Schweiz

[24] Miley, D. V; Calabra, A.E.: A review of specimen mounting methods for metallography, in: Metallogr. Specim. Prep. Opt. electron Microsc., J.L. Mccall, W.M. Mueller (Eds.), Plenum Press, London, 1974

DOI: 10.1007/978-1-4615-8708-8_1

[25] Turk, C.; Kellezi, G.; Leitner, H.; Clemens, H.; Primig, S.: Pract. Metallogr. 52 (2015), Nr. 6, 323-333

DOI: $10.3139 / 147.110344$

[26] Schumann, H.: Metallografie, 13.Auflage, Deutscher Verlag für Grundstoffindustrie $\mathrm{GmbH}, 1991$

[27] Vander Voort, G.F.: Microstructure of titanium and its alloys, in: Ind. Heat., Nr. 73, 2006 
[28] Dutta, B.; Froes, F.H.: Additive manufacturing of Titanium alloys: state of the art, challenges and opportunities, Butterworth-Heinemann, 2016

DOI: 10.1016/B978-0-12-804782-8.00003-3

[29] Barnes, D.: Metallogr. Microstruct. Anal. 5 (2016), Nr. 6, 536-539

DOI: 10.1007/s13632-016-0320-y

[30] Schiebold, K.: Zerstörende Werkstoffprüfung: Metallographische Werkstoffprüfung und Dokumentation der Prüfergebnisse, SpringerVerlag, Berlin, 2018

DOI: 10.1007/978-3-662-57803-2

\section{Christian Fleißner-Rieger}

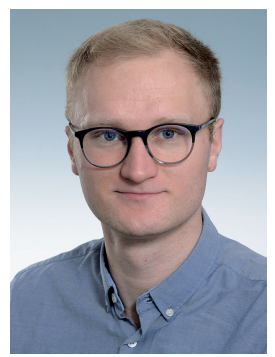

was born 1993 in Innsbruck, Austria. He studied Materials Science at the Montanuniversität Leoben, Austria. Currently he is working on his PhD thesis at the Department of Materials Science, Montanuniversität Leoben. His research work focuses on additive manufacturing of titanium alloys with a special focus on alloy development.
[31] Petzow, G.: Metallographisches, Keramographisches, Plastographisches Ätzen, 7. Auflage, Borntraeger Gebrueder, 2015

\section{Bibliography}

DOI 10.1515/pm-2020-0001

Pract. Metallogr. 58 (2021) 1; page 4-31

(C) 2021 Walter de Gruyter $\mathrm{GmbH}$, Berlin/Boston, Germany

ISSN 0032-678X · e-ISSN 2195-8599

\section{Thomas Pogrielz}

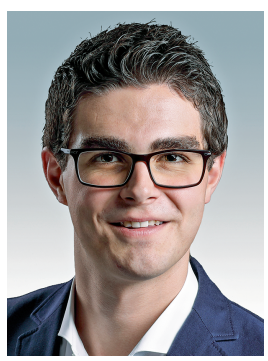

is master student in the field of Materials Science at the Montanuniversität Leoben. In his bachelor thesis at the Department of Materials Science he dealt with metallographic preparation methods for the application on additively manufactured titanium alloys. 